\title{
Elimination of the Characterization of DWPF Pour Stream Sample and the Glass Fabrication and Testing of the DWPF Sludge Batch Qualification Sample
}

J. W. Amoroso

D. K. Peeler

T. B. Edwards

May 2012 
SRNL-STI-2012-00157

Revision 0

\section{DISCLAIMER}

This work was prepared under an agreement with and funded by the U.S. Government. Neither the U.S. Government or its employees, nor any of its contractors, subcontractors or their employees, makes any express or implied:

1. warranty or assumes any legal liability for the accuracy, completeness, or for the use or results of such use of any information, product, or process disclosed; or

2. representation that such use or results of such use would not infringe privately owned rights; or

3. endorsement or recommendation of any specifically identified commercial product, process, or service.

Any views and opinions of authors expressed in this work do not necessarily state or reflect those of the United States Government, or its contractors, or subcontractors.

\section{Printed in the United States of America \\ Prepared for U.S. Department of Energy}


Keywords: Pour Stream

Sample, Sludge Batch Qualification Sample, DWPF, GPCP, WCP, Variability Study

Retention: Permanent

\title{
Elimination of the Characterization of DWPF Pour Stream Sample and the Glass Fabrication and Testing of the DWPF Sludge Batch Qualification Sample
}

\author{
J. W. Amoroso \\ D. K. Peeler \\ T. B. Edwards
}

May 2012 


\section{REVIEWS AND APPROVALS}

AUTHORS:

J.W. Amoroso, Process Technology Programs

Date

D. K. Peeler, Process Technology Programs

Date

T. B. Edwards, Applied Computational Engineering and Statistics

Date

TECHNICAL REVIEW:

K. M. Fox, Process Technology Programs

Date

APPROVAL:

C. C. Herman, Manager

Date

Process Technology Programs

S.L. Marra, Manager

Date

Environmental \& Chemical Process Technology Research Programs

J. E. Occhipinti, Manager

Date

Waste Solidification Engineering 


\section{EXECUTIVE SUMMARY}

A recommendation to eliminate all characterization of pour stream glass samples and the glass fabrication and Product Consistency Test (PCT) of the sludge batch qualification sample was made by a Six-Sigma team chartered to eliminate non-value-added activities for the Defense Waste Processing Facility (DWPF) sludge batch qualification program and is documented in the report SS-PIP-2006-00030. That recommendation was supported through a technical data review by the Savannah River National Laboratory (SRNL) and is documented in the memorandums SRNL-PSE-2007-00079 and SRNL-PSE-2007-00080. At the time of writing those memorandums, the DWPF was processing sludge-only waste but, has since transitioned to a coupled operation (sludge and salt). The SRNL was recently tasked to perform a similar data review relevant to coupled operations and re-evaluate the previous recommendations. This report evaluates the validity of eliminating the characterization of pour stream glass samples and the glass fabrication and Product Consistency Test (PCT) of the sludge batch qualification samples based on sludge-only and coupled operations.

The pour stream sample has confirmed the DWPF's ability to produce an acceptable waste form from Slurry Mix Evaporator (SME) blending and product composition/durability predictions for the previous sixteen years but, ultimately the pour stream analysis has added minimal value to the DWPF's waste qualification strategy. Similarly, the information gained from the glass fabrication and PCT of the sludge batch qualification sample was determined to add minimal value to the waste qualification strategy since that sample is routinely not representative of the waste composition ultimately processed at the DWPF due to blending and salt processing considerations. Moreover, the qualification process has repeatedly confirmed minimal differences in glass behavior from actual radioactive waste to glasses fabricated from simulants or batch chemicals.

In contrast, the variability study has significantly added value to the DWPF's qualification strategy. The variability study has evolved to become the primary aspect of the DWPF's compliance strategy as it has been shown to be versatile and capable of adapting to the DWPF's various and diverse waste streams and blending strategies. The variability study, which aims to ensure durability requirements and the PCT and chemical composition correlations are valid for the compositional region to be processed at the DWPF, must continue to be performed. Due to the importance of the variability study and its place in the DWPF's qualification strategy, it will also be discussed in this report.

An analysis of historical data and Production Records indicated that the recommendation of the Six Sigma team to eliminate all characterization of pour stream glass samples and the glass fabrication and PCT performed with the qualification glass does not compromise the DWPF's current compliance plan. Furthermore, the DWPF should continue to produce an acceptable waste form following the remaining elements of the Glass Product Control Program; regardless of a sludge-only or coupled operations strategy. If the DWPF does decide to eliminate the characterization of pour stream samples, pour stream samples should continue to be collected for archival reasons, which would allow testing to be performed should any issues arise or new repository test methods be developed. 


\section{TABLE OF CONTENTS}

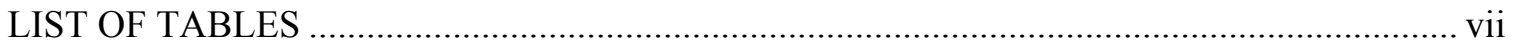

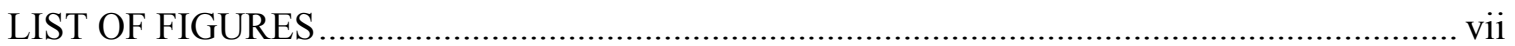

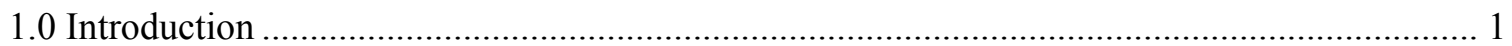

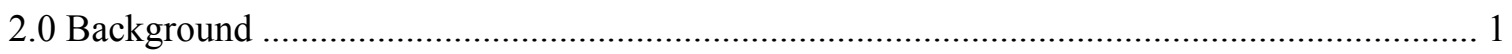

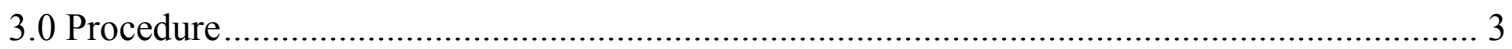

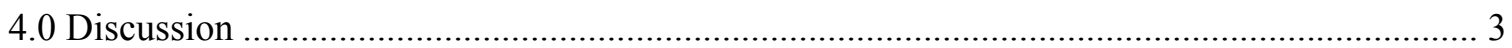

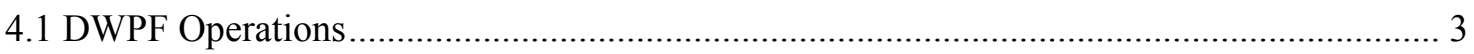

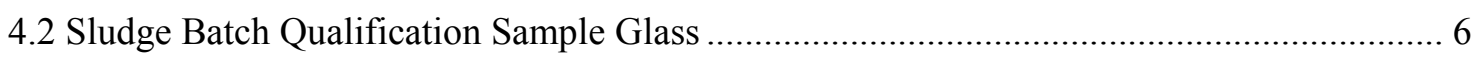

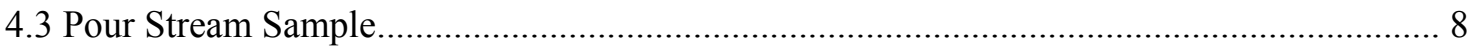

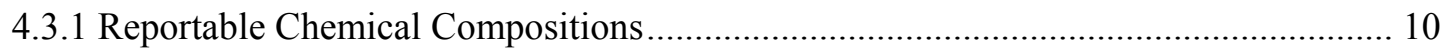

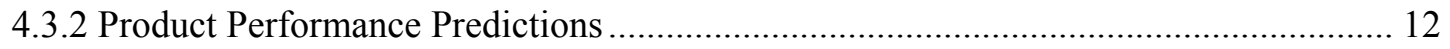

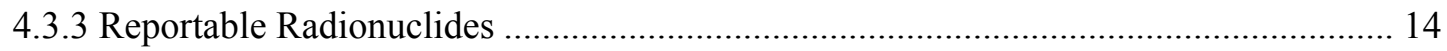

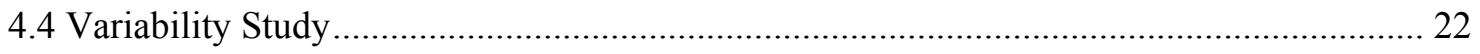

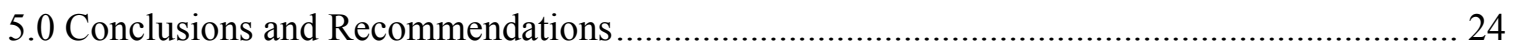

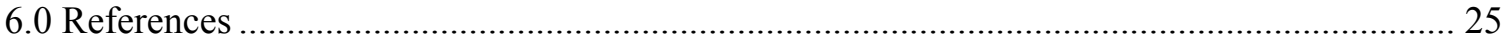




\section{LIST OF TABLES}

Table 4-1. List of Experimental Samples Currently Supporting the GPCP as part of the DWPF's Compliance Strategy (WCP).

Table 4-2. Ti and Cs Concentrations in the Pour Stream Samples and Corresponding SME Batches.*

Table 4-3. Reportable Chemical Compositions Measured from SME and Pour Stream Samples.

Table 4-4. Normalized Elemental Releases (g/L) Predicted for Macrobatch and SME Samples and Measured for Pour Stream Samples

Table 4-5. Reportable Radionuclides Measured in the Sludge and the Pour Stream Sample from Macrobatch 1 (SB1A)*

Table 4-6. Reportable Radionuclides Measured in the Sludge and the Pour Stream Sample from Macrobatch 2 (SB1B)

Table 4-7. Reportable Radionuclides Measured in the Sludge and the Pour Stream Sample from Macrobatch 3 (SB2) ${ }^{*}$.

Table 4-8. Reportable Radionuclides Measured in the Sludge and the Pour Stream Sample from Macrobatch 4 (SB3). ${ }^{*}$

Table 4-9. Reportable Radionuclides Measured in the Sludge and the Pour Stream Sample from Macrobatch 5 (SB4).

Table 4-10. Reportable Radionuclides Measured in the Sludge and the Pour Stream Sample from Macrobatch 6 (SB5). ${ }^{*}$

Table 4-11. Reportable Radionuclides Measured in the Sludge and the Pour Stream Sample from Macrobatch 7 (SB6). ${ }^{*}$

Table 4-12. Target Composition Ranges for the Variability Studies Compared to the Measured Pour Stream Samples for WAPS Reportable Chemical Compositions for SB1A through SB6.

\section{LIST OF FIGURES}

Figure 4-1. Process Flow Diagrams for Waste Processed through the DWPF Showing Samples used to Support the GPCP as Part of the DWPF's Compliance Strategy (WCP)......

Figure 4-2. THERMO ${ }^{\mathrm{TM}}$ Models with a 95\% Confidence Limit for an Individual PCT Measurement 


\section{LIST OF ABBREVIATIONS}

$\begin{array}{ll}\text { ARP } & \text { Actinide Removal Process } \\ \text { CRWMS } & \text { Civilian Radioactive Waste Management System } \\ \text { DOE } & \text { Department of Energy } \\ \text { DOE-HQ } & \text { Department of Energy - Headquarters } \\ \text { DWPF } & \text { Defense Waste Processing Facility } \\ \text { EA } & \text { Environmental Assessment } \\ \text { EM } & \text { Environmental Management } \\ \text { GPCP } & \text { Glass Product Control Program } \\ \text { HLW } & \text { High-Level Radioactive Waste } \\ \text { MCU } & \text { Modular Caustic Side Solvent Extraction Unit } \\ \text { MST } & \text { Monosodium Titanate } \\ \text { PCCS } & \text { Product Composition Control System } \\ \text { PCT } & \text { Product Consistency Test } \\ \text { SB } & \text { Sludge Batch } \\ \text { SCIX } & \text { Small Column Ion Exchange } \\ \text { SDF } & \text { Sludge Dilution Factor } \\ \text { SME } & \text { Slurry Mix Evaporator } \\ \text { SRAT } & \text { Sludge Receipt and Adjustment Tank } \\ \text { SRNL } & \text { Savannah River National Laboratory } \\ \text { SRS } & \text { Savannah River Site } \\ \text { SWPF } & \text { Salt Waste Processing Facility } \\ \text { TTR } & \text { Technical Task Request } \\ \text { WAPS } & \text { Waste Acceptance Product Specifications } \\ \text { WCP } & \text { Waste Form Compliance Plan } \\ \text { WSE } & \text { Waste Solidification Engineering } \\ \text { WQR } & \text { Waste Form Qualification Report } \\ & \end{array}$




\subsection{Introduction}

In 2006 a Six Sigma team chartered to eliminate non-value added activities for the Defense Waste Processing Facility (DWPF) sludge batch qualification program identified two activities that were adding minimal value to information being compiled to demonstrate waste form compliance. That team recommended the elimination of the characterization of pour stream glass samples and the elimination of the glass fabrication ${ }^{\mathrm{a}}$ and Product Consistency Test (PCT) of the sludge batch qualification sample. $^{1}$

In 2007 the Savannah River National Laboratory (SRNL) issued two memorandums ${ }^{2,3}$ that provided technical justification, through data reviews, supporting the Six Sigma team recommendations. However, no data existed for coupled operations (i.e., introduction of auxiliary streams from the Modular Caustic Side Solvent Extraction Unit (MCU) / Actinide Removal Process (ARP) or the Salt Waste Processing Facility (SWPF)) at the time the two SRNL memorandums were issued. Nevertheless, in both documents, it was stated that the recommended compliance strategy changes (pour stream and sludge batch qualification sample elimination) would also apply to DWPF coupled processing because the strategy for coupled operation of sludge with an auxiliary salt processing stream, e.g., a Cs-137 laden stream, would utilize Slurry Mix Evaporator (SME) predictions and require characterization (to comply with the Waste Acceptance Product Specifications (WAPS)) of the batches to be processed in DWPF in the same manner as the sludge-only reporting process. However, ultimately no compliance strategy changes were implemented based on the 2007 data review because of a Department of Energy Headquarters (DOE-HQ) request to postpone any changes during the submittal of the disposal facility license application. Salt streams (ARP/MCU) were introduced into DWPF in 2008 and SRNL was tasked again in 2011 to evaluate the existing DWPF Glass Product Control Program (GPCP) compliance strategies (specifically associated with pour stream sampling and sludge batch qualification) and determine whether strategy changes are warranted. ${ }^{4}$

This evaluation was specifically intended to include the additional coupled operations data from the DWPF processing that had been generated since the initial SRNL memorandums were issued. The intent of evaluating these additional data was to assess whether the recommendations previously made are still valid given the transition from sludge-only to coupled operations processing in DWPF. In addition, although the SWPF has not come on-line and hence, no experimental data are available, the SWPF will be integrated into the DWPF in the future and this report therefore will also evaluate the projected SWPF impact as it relates to the two recommendations.

This work was performed in response to a Technical Task Request (TTR) ${ }^{4}$ from DWPF Waste Solidification Engineering (WSE) and was controlled under a Task Technical and Quality Assurance Plan. ${ }^{5}$

\subsection{Background}

The U.S. Department of Energy (DOE) Office of Environmental Management (EM) developed the WAPS for the canistered vitrified high-level radioactive waste (HLW) form by Producers [and Federal Waste Custodians] as the basis for their waste acceptance programs. The WAPS are technical specifications the waste form Producers are required to meet in order to ensure acceptance of their vitrified HLW waste form into the DOE Civilian Radioactive Waste

\footnotetext{
${ }^{\text {a }}$ To complete the SME for sludge batch qualification, a frit will still have to be blended with the SRAT product to satisfy waste compliance and safety assessments for DWPF processing (e.g. measurements of rheology and hydrogen generation).
} 
Management System (CRWMS). The waste acceptance process requires demonstration of compliance with the WAPS via four different documents, each prepared by the Producers. These four documents are: (1) the Waste Form Compliance Plan (WCP), (2) the Waste Form Qualification Report (WQR), (3) Production Records, and (4) Storage and Shipping Records. ${ }^{6}$

The specific requirements associated with the waste form (HLW borosilicate glass) are outlined in Section 1 of the WAPS and require the DWPF to ${ }^{\text {b. }}$

1.1 Report the oxide composition of the waste form for any element present at $>0.5$ wt. \%;

1.2 Report the inventory of radionuclides that have half-lives longer than 10 years and contribute $>0.05$ percent of the total Curie inventory indexed to the years 2015 and 3115

1.3 Demonstrate control of the waste form production by comparing, either directly (measurements) or indirectly (predictions), production samples to the Environmental Assessment (EA) benchmark glass; and

1.6 Report the isotopic composition of uranium and plutonium in the waste form.

The DWPF controls the melter feed composition at the SME in order to meet the WAPS requirements as documented in the DWPF's WCP. In order to demonstrate compliance of the waste form, the DWPF indirectly (non-experimental) makes use of predictive property models appropriate for the waste form. As with any model, experimental evidence was used to validate its accuracy and usefulness. However, when DWPF was developing its waste compliance strategy, the DWPF was the only HLW vitrification plant of its design in the United States and no experimental data existed for the waste form processed through the facility and only limited radioactive laboratory-scale data was available. Consequently, the DWPF developed the GPCP as part of its compliance strategy to further ensure and demonstrate (as best as possible) the success of its compliance protocol and thereby produce a waste form compliant with the WAPS. During Waste Qualification Runs, the DWPF demonstrated the validity of the GPCP, and the results were documented in the WQRs. After radioactive start-up, the DWPF continued to use some of these same aspects (e.g., qualification sample analyses and processing, SME analyses and predictions of acceptability, the variability study, and pour stream sample confirmation) to demonstrate compliance. Verification of compliance was provided in the DWPF's Production Records and in the Storage and Shipping Records.

The DWPF currently uses a combination of model predictions and experimental data to achieve the GPCP compositional control objectives. The SRNL continues to support a significant portion of that effort both experimentally and computationally. According to Section 3.5 of the GPCP, revision $6,{ }^{7}$ for each sludge and salt batch, the SRNL will:

- characterize the chemical composition and radionuclide inventory of samples received from the tank farm,

- demonstrate that the waste from the tank farm will produce an acceptable glass,

- demonstrate that chemical compositions and durability correlations are applicable to the waste to be processed through the DWPF,

- characterize any pour stream samples that are taken,

- archive pour stream samples, and

- provide results to DWPF WSE for inclusion in the Production Records.

\footnotetext{
${ }^{\mathrm{b}}$ Although the WAPS includes specifications 1.4 and 1.5 , they are not specifically satisfied with the sludge batch qualification sample glass or the pour stream sample.
} 
As originally implemented, the GPCP included the variability study, the characterization of the sludge batch qualification glass product, and the characterization of the pour stream sample for each sludge and salt batch. The characterization of the qualification sample glass product and the characterization of the pour stream sample were intended to be direct experimental confirmation of the models' predictions for each macrobatch. The variability study, on the other hand, was intended to demonstrate the durability models applicability to possible variations about the mean macrobatch composition for that particular sludge or macrobatch. Although the form of the variability study is not explicit in the WCP or WQRs, the variability study has historically included model predictions over the expected glass composition range followed by experimental measurements on a matrix of glasses covering the anticipated waste compositions.

Since production began, the relevance of the characterization of the qualification glass sample has diminished significantly as to question its usefulness. Similarly, the characterization of the pour stream sample has confirmed the validity of the DWPF's SME acceptability measurements and qualification/WAPS sample characterization, but ultimately results of the characterization have not affected the DWPF's reporting requirements. In contrast, the variability study has evolved to become a key aspect of the DWPF's compliance strategy as it has been shown to be versatile and capable of adapting to the DWPF's various waste streams and blending strategies.

\subsection{Procedure}

No experimental data were generated during this task. Instead, the pertinent data were gleaned from pre-existing reports and compiled into this data review report. The sources for material in this report were U.S. Government reports and memorandums, the DWPF Production Records, and personal communications. As this report was being prepared, the DWPF operations data were current through Sludge Batch 6 (SB6). This report therefore evaluates Sludge Batch 1A (SB1A) thru SB6.

To provide a more complete data review and analysis and in turn recommendation, an attempt was made to compile complete data sets. Therefore, some of the data that are presented in this report are redundant to those documented in the previous two memorandums. ${ }^{2,3}$ The purpose was to ensure that as complete a data set as possible was provided in this report by including any relevant information not included in the previous data reviews and updating data relevant to the sludge batches processed after the previous memorandums were issued.

The intent of this report is to provide a technical analysis of historical data so that the DWPF can justify the elimination of the characterization of pour stream glass samples and the elimination of the glass fabrication and PCT of the sludge batch qualification sample. At the same time, the variability study, which is the primary method for demonstrating acceptability and the correlation between the glass composition and its PCT response, will be examined as it applies to the DWPF's WCP. Ultimately, an encompassing recommendation for the activities performed with respect to this task for the DWPF to meet waste form compliance will be made.

\subsection{Discussion}

\subsection{DWPF Operations}

There have been three major developments in the DWPF's HLW processing plan with respect to sludge preparation and sludge feed. The reasons for the process changes are many but, the combination of 1) the tank waste composition and 2) the limited transfer lines in the tank farm 
between tanks and from the tank farm to the DWPF are among the most significant. The discussion that follows is informative only and intended to explain the processing plans and strategy changes that have occurred at the DWPF since the start of radioactive operations with respect to the sludge batch qualification sample and the pour stream sample as they will be referred to later.

The DWPF originally planned to have two feed tanks (Tank 40 and Tank 51) in which the waste in one tank would be prepared and qualified at the same time that the waste in the other tank was being processed. The DWPF began processing sludge-only (Sludge Batch 1A (SB1A)) waste that was qualified in, and fed to the DWPF from, Tank 51. Then, during SB1A processing the DWPF chose to blend material that had been previously qualified in a separate tank (Tank 42) with the remaining heel from SB1A in Tank 51 to form sludge batch 1B (SB1B). SB1B signifies that very early into processing HLW, the DWPF had chosen to accept that a sludge batch prepared from a blend of previously qualified sludge material would itself be considered qualified. The next sludge batch, Sludge Batch 2 (SB2), was processed similar to SB1A in that the waste was qualified in the same tank from which it was fed to the DWPF; in that case Tank 40. At that time, the Savannah River Site (SRS) shifted focus to accelerated closure by increasing the DWPF's throughput which reduced the time allowable to prepare a batch and perform a sludge batch qualification prior to processing. As a result, the DWPF shifted to qualifying future sludge batches in one tank (Tank 51) while using the other tank (Tank 40) as the feed tank during processing of the sludge batch. Sludge Batch 3 (SB3) was the first sludge batch to be processed using that revised processing plan; SB1B was effectively processed in the same way although for different reasons. Towards the completion of processing Sludge Batch 4 (SB4) the DWPF initiated coupled operations in which it began feeding auxiliary salt streams in combination with the sludge stream. Subsequent Sludge Batches 5 and 6 (SB5 and SB6) were both processed under coupled operations.

Throughout the waste processing operation several waste samples are taken and characterized. The current DWPF compliance strategy utilizes information obtained from those samples to demonstrate compliance with Section 1 of the WAPS. Figure 4-1 illustrates the evolution of the major processes and sample points for HLW processed through the DWPF to date. The information obtained from each sample and the WAPS requirements addressed are summarized in Table 4-1. Items in italic font are those directly associated with the TTR. ${ }^{4}$ 


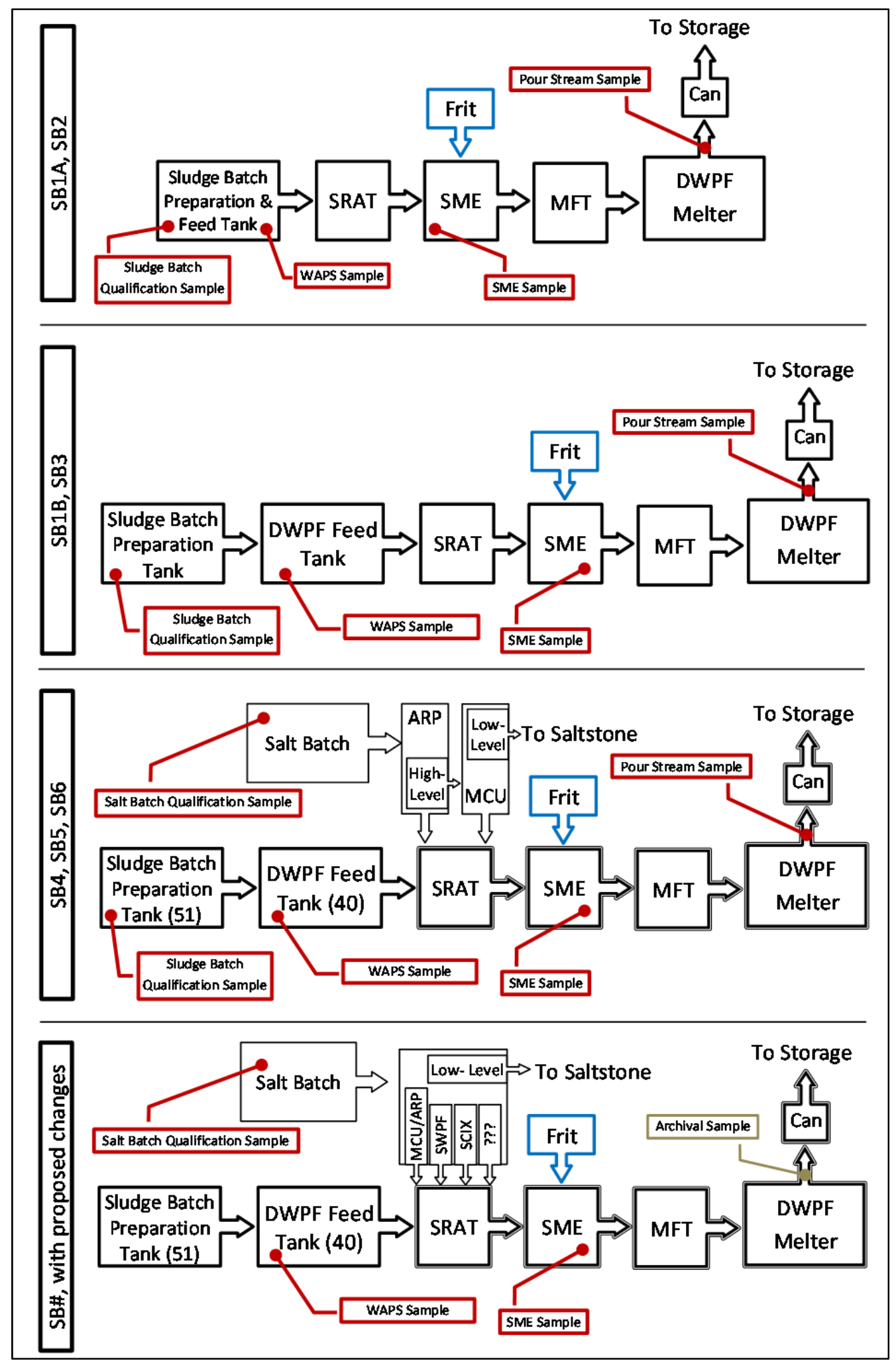

Figure 4-1. Process Flow Diagrams for Waste Processed through the DWPF Showing Samples used to Support the GPCP as Part of the DWPF's Compliance Strategy (WCP). Sludge Only Operations Denoted by (—); Coupled Operations Denoted by ( $=$ ). 
SRNL-STI-2012-00157

Revision 0

Table 4-1. List of Experimental Samples Currently Supporting the GPCP as part of the DWPF's Compliance Strategy (WCP).

\begin{tabular}{|c|c|c|c|}
\hline Sample & Performer & Information & $\begin{array}{c}\text { WAPS } \\
\text { Specifications }^{6}\end{array}$ \\
\hline $\begin{array}{l}\text { (Tank 51) Sludge Batch } \\
\text { Qualification Sample }\end{array}$ & SRNL & $\begin{array}{l}\text { - } \text { chemical composition } \\
\text { - } \text { radionuclide inventory } \\
\text { - proof of vitrification } \\
\text { - durability prediction }\end{array}$ & $\begin{array}{l}-1.1 \\
-1.2 \\
-1.3 \\
-1.6 \\
\end{array}$ \\
\hline Tank 40 (WAPS) Sample & SRNL & $\begin{array}{l}\text { - chemical composition } \\
\text { - radionuclide inventory }\end{array}$ & $\begin{array}{l}-1.1 \\
-1.2 \\
-1.6 \\
\end{array}$ \\
\hline Pour Stream Sample & SRNL & $\begin{array}{l}\text { - chemical composition } \\
\text { - radionuclide inventory } \\
\text { - durability } \\
\text { - archival record } \\
\end{array}$ & $\begin{array}{l}-1.1 \\
-1.2 \\
-1.3 \\
-1.6 \\
\end{array}$ \\
\hline SME Sample & DWPF & $\begin{array}{l}\text { - chemical composition } \\
\text { - durability prediction }\end{array}$ & $\begin{array}{l}-1.1 \\
-1.3 \\
\end{array}$ \\
\hline
\end{tabular}

*Italic font indicates those elements affected by potential compliance strategy changes related to eliminating the sludge batch qualification sample glass and the pour stream glass characterization.

\subsection{Sludge Batch Qualification Sample Glass}

The sludge batch qualification sample was originally intended to represent the sludge composition to be processed through the DWPF. In principle, a sample is taken from the DWPF feed tank and analyzed by the SRNL in the shielded cells where the sample is processed through the typical DWPF Sludge Receipt and Adjustment Tank (SRAT) and SME cycles and a portion of the SME material is converted to glass. That glass is then analyzed for composition and subjected to the PCT to determine durability. The results of the sludge batch qualification glass are used to demonstrate production of an acceptable glass and to support the assessment of the applicability of the current durability models.

Although the intent of the sludge batch qualification sample glass was to assess the final waste form performance, accelerated tank closures and coupled operations ${ }^{\mathrm{c}}$ at the DWPF created a situation in which the composition of the sludge batch qualification sample was not representative of the waste processed through the DWPF. To be clear, the sludge batch qualification changes were not considered a compliance strategy risk since SRNL would continue to analyze a separate WAPS sample, ${ }^{\mathrm{d}}$ and the sludge batch qualification would be performed on a sludge that would ultimately be blended with a previously qualified sludge (heel). ${ }^{\mathrm{e}}$

SB1A and SB2 are the only sludge batches (to date) in which the sludge batch qualification sample composition reflected the composition of the waste processed through the DWPF. That is

\footnotetext{
${ }^{\mathrm{c}}$ Coupled operations were instituted to process the high-level salt batches.

${ }^{\mathrm{d}}$ The WAPS sample is taken from the DWPF feed tank (currently tank 40) after all transfers have been completed and is analyzed for reportable chemical compositions (WAPS 1.1) and reportable radionuclides (WAPS 1.2).

${ }^{\mathrm{e}}$ The rationalization for blending in this way was that independently qualified sludge batches, when mixed, would constitute a qualified sludge batch.
} 
to say, the DWPF's feed tank (at that time) was the same tank from which the sludge qualification sample originated and no auxiliary salt streams were added. For those sludge batches a review of the PCT data ${ }^{\mathrm{f}}$ indicated that the PCT response of the glass made from each sludge batch qualification sample was acceptable. In contrast, the sludge batch qualification samples for SB1B, SB3, SB4, SB5, and SB6 did not reflect the sludge composition to be processed in the DWPF (due to blending and coupled operations). ${ }^{\mathrm{g}}$ Accordingly, the sensibility of performing the glass fabrication and PCT from the sludge batch qualification sample in those instances is ambiguous.

The previous memorandum examined SB1A through SB4 and concluded the following: ${ }^{2}$

...elimination of the fabrication and characterization of the qualification [glass] sample does not compromise the qualification process.

This decision [recommendation] will not be impacted by the current salt processing strategy because the variability studies for those sludge batches will consider coupled operations.

...these tests [fabrication and characterization of the qualification glass sample] have provided little added value to the information gained during the variability study, which is a required element of the DWPF GPCP and is the primary means for demonstrating the DWPF compliance with the WAPS specification 1.3.

Since the previous memorandum was issued, SB5 and SB6 have been processed through the DWPF. Those sludge batches were processed in a similar manner to SB4 illustrated in Figure 4-1 and as such, the above listed recommendations remain credible. ${ }^{\mathrm{h}}$ That is, vitrifying a portion of the sludge batch qualification sample and measuring the PCT response provide minimal added value to the DWPF's compliance strategy if the sludge batch preparation plans continue to provide sludge batch qualification samples that do not represent the waste composition to be processed through the DWPF.

Instead, an effectively designed variability study targeting a blend composition that includes auxiliary waste streams (MCU/ARP and SWPF) and the recommended frit covering a waste loading range of interest based on process control models, melt rate, and waste throughput can be used to meet compliance. The variability study has always been used for confirming model applicability and glass acceptability. With the accelerated closure efforts at the SRS, demonstration of the durability models' applicability (WAPS specification 1.3) has increasingly shifted to the more encompassing variability study that evaluates a composition region focused on the blended feed and the impact of the salt streams. The variability study will be further examined in Section 4.4.

\footnotetext{
${ }^{\mathrm{f}}$ Refer to previous memorandum SRNL-PSE-2007-00080.

${ }^{g}$ Although not obvious, frit changes within the DWPF can also contribute to the glass composition discrepancies. Indeed this was the case during SB4 in which Frit 510 was processed but, Frit 507 was used for the qualification glass since it was more suited for the qualification glass

${ }^{\mathrm{h}}$ Coupled operations do not change the SRNL recommendation since salt blending takes place in the SRAT and the sludge batch qualification sample continues to not represent the actual waste processed through the DWPF.
} 


\subsection{Pour Stream Sample}

The DWPF has been collecting at least two glass pour stream samples from each macrobatch to submit to the SRNL for analysis as part of the DWPF's compliance strategy. ${ }^{7}$ One glass sample has been used for characterization and one has been archived for possible future needs. Characterization of the glass pour stream samples at SRNL has been performed to provide supporting information to demonstrate waste form compliance with the WAPS ${ }^{6}$ for chemical composition, product performance, and radionuclide inventory.

Although the DWPF began coupled operations during SB4 processing, to support this study it was necessary to determine whether each pour stream sample composition represented a coupled operation SME batch or a sludge only SME batch because the DWPF introduces auxiliary salt waste streams from the MCU and ARP into the SRAT intermittently. ${ }^{\mathrm{i}}$ To do that, Cs and Ti concentrations in the pour stream samples were used to track salt stream additions through the DWPF process. Specifically, the auxiliary salt streams from the ARP and MCU are laden with significantly higher concentrations of $\mathrm{Ti}$ and $\mathrm{Cs}$, respectively, compared to their concentrations in the sludge. This feature (of coupled operations) was used to track salt stream additions through the DWPF process and to link the analytical results of the pour stream samples to a coupled operations flow sheet.

Table 4-2 summarizes the measured $\mathrm{Ti}(\mathrm{wt} . \%)$ and $\mathrm{Cs}-137(\mathrm{Ci} / \mathrm{kg})$ concentrations for the qualification sludge solids ${ }^{\mathrm{j}}$ and pour stream samples from SB1A through SB6. The measured Ti concentration in the sludge solids averaged $0.02 \mathrm{wt} \%$ and remained relatively unchanged for all sludge batches listed. The measured Cs concentration in the sludge solids had a larger standard deviation compared to the Ti values, but was also relatively constant and averaged $0.25 \mathrm{Ci} / \mathrm{kg}$.

To determine whether the pour stream samples represented coupled operations, the measured $\mathrm{Ti}$ and Cs concentrations from the pour stream samples were compared to the measured $\mathrm{Ti}$ and $\mathrm{Cs}$ concentrations from the sludge solids to obtain a relative concentration. The relative $\mathrm{Cs}$ and $\mathrm{Ti}$ concentrations indicated that the SB4 pour stream sample was not representative of a coupled operation process. However, SB5 and SB6 pour stream samples were representative of waste processed via a coupled operation as evidenced by an increase $(\sim 2 \mathrm{x})$ in the relative $\mathrm{Ti}$ concentration measured in the SB5 pour stream sample and a larger increase $(\sim 10 \mathrm{x})$ in the relative $\mathrm{Ti}$ and $\mathrm{Cs}$ concentrations measured in the SB6 pour stream sample. It was concluded that the measured increase in relative $\mathrm{Ti}$ and $\mathrm{Cs}$ concentration indicated that the SB5 pour stream sample represented an ARP coupled operation ${ }^{\mathrm{k}}$ and the SB6 pour stream sample represented an ARP and MCU coupled operation.

\footnotetext{
${ }^{\mathrm{i}}$ One reason for the intermittent salt additions is that the MCU and the ARP cannot process the salt volume to keep pace with the sludge volume. Long term predictions indicate that the current salt processing capabilities are not adequate to process the remaining volume of salt waste in the same time period as the sludge can be processed. The SWPF, which is currently being built, will alleviate that issue.

${ }^{\mathrm{j}}$ The qualification sludge solids represent solids prior to adding frit.

${ }^{\mathrm{k}} \mathrm{MCU}$ may also have been added but, was not detectable from the Cs content.
} 
Table 4-2. Ti and Cs Concentrations in the Pour Stream Samples and Corresponding SME Batches.

\begin{tabular}{|c|c|c|c|c|c|c|c|c|c|c|c|c|c|c|}
\hline \multirow{3}{*}{$\begin{array}{l}\text { Macro } \\
\text { Batch }\end{array}$} & \multirow{3}{*}{$\begin{array}{c}\text { Sludge } \\
\text { Batch }\end{array}$} & \multirow{3}{*}{ Operation } & \multicolumn{2}{|c|}{ Pour Stream } & \multirow{3}{*}{$\begin{array}{l}\text { Sludge } \\
\text { Solids }\end{array}$} & \multirow{2}{*}{\multicolumn{3}{|c|}{$\begin{array}{l}\text { Ti (wt. \%) } \\
\text { Glass Basis }\end{array}$}} & \multirow{3}{*}{$\begin{array}{l}\text { Sludge } \\
\text { Solids }\end{array}$} & \multirow{2}{*}{\multicolumn{3}{|c|}{$\begin{array}{r}\text { Cs-137 (Ci/kg) }{ }^{\dagger} \\
\text { Glass Basis }\end{array}$}} & \multirow{3}{*}{$\begin{array}{c}\text { Auxiliary } \\
\text { Stream } \\
\text { Represented } \\
\text { in Pour } \\
\text { Stream }\end{array}$} & \multirow{3}{*}{ Source(s) } \\
\hline & & & \multirow{2}{*}{$\begin{array}{c}\text { Canister } \\
\text { ID }\end{array}$} & \multirow{2}{*}{$\begin{array}{l}\text { SME } \\
\text { Batch }\end{array}$} & & & & & & & & & & \\
\hline & & & & & & Solids $^{\ddagger}$ & SME & Pour & & Solids $^{\ddagger \ddagger}$ & SME & Pour & & \\
\hline $1^{i}$ & SB1A & Sludge Only & S00834 & 81 & 0.02 & - & $0.02^{i}$ & 0.01 & 0.06 & 0.02 & $0.02^{\mathrm{ii}}$ & 0.02 & - & $8-10$ \\
\hline $2^{i}$ & $S B 1 B$ & Sludge Only & S01142 & 123 & 0.02 & - & $0.17^{i}$ & 0.04 & 0.16 & 0.06 & $0.05^{\mathrm{ii}}$ & 0.05 & - & $11-14$ \\
\hline $3^{\mathrm{ii}}$ & $S B 2$ & Sludge Only & S01913 & 254 & 0.02 & - & $0.03^{i}$ & 0.04 & 0.28 & 0.11 & $0.11^{\mathrm{iii}}$ & 0.09 & - & $15-19$ \\
\hline $4^{\mathrm{ii}}$ & SB3 & Sludge Only & S02312 & 319 & 0.02 & - & $0.04^{i}$ & 0.04 & 0.32 & 0.15 & $0.15^{\mathrm{iii}}$ & 0.15 & - & $20-22$ \\
\hline $5^{i i i}$ & SB4 & Coupled & S02902 & 435 & 0.02 & - & $0.04^{i}$ & 0.04 & 0.25 & 0.11 & $0.11^{i v}$ & 0.10 & - & $23-26$ \\
\hline $6^{\mathrm{iiii}}$ & SB5 & Coupled & S03317 & $520^{v}$ & 0.02 & - & 0.18 & 0.12 & 0.32 & 0.13 & $0.15^{\mathrm{vi}}$ & 0.17 & ARP & $25,27-29$ \\
\hline 7 & SB6 & Coupled & S03472 & 551 & 0.02 & - & $0.22^{\mathrm{vii}}$ & 0.21 & 0.39 & $0.17^{\mathrm{vii}}$ & $1.69^{\mathrm{vii}}$ & 1.3 & ARP/MCU & $30-32$ \\
\hline
\end{tabular}

${ }^{*}$ Values in this Table are the measured values transcribed from those reported in the source(s) if not otherwise indicated.

Cs-137 values are reported in various units. The conversion factor $3.7 \times 10^{10} \mathrm{~Bq} / \mathrm{Ci}$ was used to standardize the units.

${ }^{\ddagger}$ The Ti solids values were not calculated because Ti is a Frit impurity and its measured concentration is significantly dependent on the analysis method.

${ }^{\ddagger \ddagger}$ Cs-137 solids values were obtained by dividing the sludge solids by the Sludge Dilution Factor (SDF) reported in the Production Records inputs. (References 8,12,15,21,24,28)

${ }^{\mathrm{i}}$ Source: Personal communication with Hank Elder.

${ }^{\text {ii }}$ The DWPF did not begin measuring SME samples until SB2. Therefore the 'SME' Cs- 137 values are the reported measured values from the MFT samples in Reference 8 and 12 respectively.

iii During SB2 and SB3 the DWPF operated according to Revision 2 of the WQR volume 4. In that Revision, MFT sampling was eliminated and Cs-137 inventories were no longer directly measured but, were calculated from measured sludge qualification samples. The Cs-137 SME values were obtained using the reported average Ci/canister and equation (6) in Reference 15 and 21.

iv The DWPF began measuring Cs-137 again at the start of SME batch 449 due to the addition of the MCU salt stream (strip effluent) to SB4. However, the pour stream was taken while processing SME batch 435, before MCU was added. The Cs-137 SME value was calculated using the reported total Ci for SME batches 402-448, equation (5), and the SDF in Reference 24.

${ }^{v}$ Canister S03317 was being filled while the DWPF transferred SME batch 521 to the MFT. Consequently some reports indicate that SME batch 521 was being fed to the melter during filling of that canister. However, given the residence time in the melter (for an MFT batch) the material in canister S03317 was considered to be representative of SME batch 520 for analysis purposes.

${ }^{v i}$ The DWPF continued to measure Cs-137 once coupled operations began. The Cs-137 SME value was calculated from the concentration (Bq/g) reported in Reference 28.

${ }^{\text {vii }}$ Source: Personal communication with Hank Elder cross referenced to QA Batch Records. The production inputs had not been issued for SB6 at the writing of this report. 
The previous memorandum ${ }^{3}$ examined SB1A through SB3 and concluded:

... the pour stream data are redundant

1) to chemical composition measurements that are derived from SME samples,

2) to product performance predictions determined from the SME measurements, and

3) to the Product Composition Control System (PCCS) models, ${ }^{33}$ and to the radionuclide inventory measured on a sample of the macrobatch of sludge being processed in the DWPF.

In order to assess the validity of the previous conclusions with respect to coupled operations, the reportable chemical compositions, product performance predictions, and reportable radionuclide concentrations were compiled for SB1A through SB6 and are discussed in turn.

\subsubsection{Reportable Chemical Compositions}

Table 4-3 lists the WAPS reportable chemical compositions measured from the SME batches compared to those measured in the pour stream sample. The chemical compositions listed for the SME batches in Table 4-3 are an average of the DWPF's individual SME measurements over the course of the specified sludge batch. For all sludge batches, the pour stream sample and the average SME sample compositions were in good agreement $( \pm \sim 20 \%) .{ }^{1}$ Those results confirmed that the DWPF's compliance plan adequately inventoried the reportable chemical compositions in the waste form and demonstrated the redundancy of the pour stream sample characterization for SB1A through SB6.

\footnotetext{
${ }^{1}$ The average difference for all oxides (for a given sludge batch) was less than $10 \%$.
} 
Table 4-3. Reportable Chemical Compositions Measured from SME and Pour Stream Samples.*

\begin{tabular}{|c|c|c|c|c|c|c|c|c|c|c|c|c|c|c|}
\hline \multirow[b]{2}{*}{ Oxide } & \multicolumn{2}{|c|}{$\begin{array}{c}\text { Macrobatch } 1 \\
\text { SB1A }\end{array}$} & \multicolumn{2}{|c|}{$\begin{array}{c}\text { Macrobatch } 2 \\
\text { SB1B } \\
\end{array}$} & \multicolumn{2}{|c|}{$\begin{array}{c}\text { Macrobatch } 3 \\
\text { SB2 } \\
\end{array}$} & \multicolumn{2}{|c|}{$\begin{array}{c}\text { Macrobatch } 4 \\
\text { SB3 } \\
\end{array}$} & \multicolumn{2}{|c|}{$\begin{array}{c}\text { Macrobatch } 5 \\
\text { SB4 } \\
\end{array}$} & \multicolumn{2}{|c|}{$\begin{array}{c}\text { Macrobatch } 6 \\
\text { SB5 } \\
\end{array}$} & \multicolumn{2}{|c|}{$\begin{array}{c}\text { Macrobatch } 7 \\
\text { SB6 }\end{array}$} \\
\hline & $\begin{array}{c}\text { SME } \\
19-93\end{array}$ & $\begin{array}{l}\text { Pour } \\
\text { Stream } \\
\text { S00834 }\end{array}$ & $\begin{array}{c}\text { SME } \\
94-207\end{array}$ & $\begin{array}{l}\text { Pour } \\
\text { Stream } \\
\text { S01142 } \\
\end{array}$ & $\begin{array}{l}\text { SME } \\
208- \\
271 \\
\end{array}$ & $\begin{array}{l}\text { Pour } \\
\text { Stream } \\
\text { S01913 } \\
\end{array}$ & $\begin{array}{l}\text { SME } \\
272- \\
401 \\
\end{array}$ & $\begin{array}{c}\text { Pour } \\
\text { Stream } \\
\text { S02312 } \\
\end{array}$ & $\begin{array}{l}\text { SME } \\
402- \\
467 \\
\end{array}$ & $\begin{array}{c}\text { Pour } \\
\text { Stream } \\
\text { S02902 } \\
\end{array}$ & $\begin{array}{l}\text { SME } \\
468- \\
530 \\
\end{array}$ & $\begin{array}{l}\text { Pour } \\
\text { Stream } \\
\text { S03317 }\end{array}$ & $\begin{array}{l}\text { SME } \\
531- \\
569^{i}\end{array}$ & $\begin{array}{l}\text { Pour } \\
\text { Stream } \\
\text { S03472 } \\
\end{array}$ \\
\hline $\mathrm{Al}_{2} \mathrm{O}_{3}$ & 4.58 & 4.28 & 5.94 & 5.37 & 4.82 & 4.34 & 5.51 & 4.79 & 8.34 & 7.78 & 6.86 & 6.71 & 9.05 & 8.63 \\
\hline $\mathrm{B}_{2} \mathrm{O}_{3}$ & 8.57 & 8.19 & 8.06 & 8.18 & 5.8 & 4.44 & 4.68 & 4.44 & 8.16 & 8.92 & 5.19 & 5.58 & 4.69 & 4.55 \\
\hline $\mathrm{CaO}$ & 1.21 & 1.3 & 1.33 & 1.39 & 1.35 & 1.31 & 1.03 & 1.03 & 0.88 & 0.72 & 0.77 & 0.70 & 0.56 & 0.61 \\
\hline $\mathrm{Fe}_{2} \mathrm{O}_{3}$ & 11.98 & 12.56 & 11.13 & 10.50 & 13.44 & 12.17 & 11.26 & 10.80 & 9.53 & 8.21 & 8.77 & 8.53 & 8.78 & 8.74 \\
\hline $\mathrm{Li}_{2} \mathrm{O}$ & 3.65 & 3.57 & 3.41 & 3.53 & 4.58 & 5.27 & 4.76 & 4.96 & 5.12 & 5.25 & 5.33 & 5.55 & 4.88 & 4.92 \\
\hline MgO & 2.12 & 2.10 & 2.04 & 2.16 & 1.5 & 1.16 & 1.23 & 1.16 & 0.9 & 0.78 & N.R. & 0.51 & N.R. & 0.33 \\
\hline MnO & 1.09 & 1.11 & 1.51 & 1.76 & 1.54 & 1.47 & 2.01 & 2.09 & 1.84 & 1.62 & 1.84 & 1.73 & 2.35 & 2.19 \\
\hline $\mathrm{Na}_{2} \mathrm{O}$ & 11.93 & 12.08 & 11.16 & 11.50 & 11.03 & 11.31 & 11.8 & 11.90 & 10.91 & 11.5 & 12.65 & 13.40 & 13.86 & 14.86 \\
\hline $\mathrm{NiO}$ & N.R. & N.R. & N.R. & N.R. & N.R. & 0.55 & N.R. & 0.55 & N.R. & N.R. & 0.97 & 0.96 & 1.05 & 1.02 \\
\hline $\mathrm{SiO}_{2}$ & 50.64 & 48.1 & 50.96 & 52.40 & 48.05 & 49.31 & 50.86 & 51.00 & 50.15 & 50.7 & 52.52 & 54.60 & 48.37 & 49.10 \\
\hline $\mathrm{ThO}_{2}$ & N.R. & N.R. & N.R. & N.R. & N.R. & N.R. & N.R. & N.R. & N.R. & N.R. & N.R. & N.R. & 1.07 & 1.00 \\
\hline $\mathrm{U}_{3} \mathrm{O}_{8}$ & 1.28 & 1.03 & 1.31 & 1.06 & 3.67 & 3.36 & $3.58^{\mathrm{ii}}$ & 3.51 & 2.51 & 2.23 & 2.3 & 2.22 & 1.82 & 1.83 \\
\hline Source & 34 & 3,9 & 35 & $3,13,14$ & 36 & 3,37 & 21,38 & $3,20,39$ & 40,41 & 25 & 42 & 25 & 43 & 32,44 \\
\hline
\end{tabular}

*Values in this Table are the measured values transcribed from those reported in the source(s) if not otherwise indicated. WAPS specification 1.1 requires all elemental (except for oxygen) concentrations $>0.5 \mathrm{wt}$. \% in glass to be reported as an oxide basis.

N.R. = Not reportable.

Source: Personal communication with Hank Elder cross referenced to QA Batch Records. The production inputs had not been issued for SB6 at the writing of this report.

${ }^{\text {ii }}$ Calculated using the reported U wt. \% in glass reported in Reference 21 and the gravimetric factor 1.1792 to convert from elemental to oxide weight percent. 


\subsubsection{Product Performance Predictions}

Table 4-4 lists the predicted PCT results for the macrobatches and SME samples, the measured PCT results for the pour stream samples, and the PCT response of the Environmental Assessment (EA) benchmark glass. All of the pour stream glasses exhibited nominal elemental release rates below the WAPS requirement. The predictability of the PCT results for the glass pour stream samples is demonstrated by showing that the measured values for the PCT were within the appropriate uncertainty intervals for the values that were predicted by the THERMO ${ }^{\mathrm{TM}}$ models. ${ }^{45}$ Figure 4-2 shows the THERMO ${ }^{\mathrm{TM}}$ models for $\mathrm{B}, \mathrm{Li}$, and $\mathrm{Na}$ with a $95 \%$ confidence interval (the shaded region) for the PCT for an individual glass. These plots were generated using JMP Version 7.0.2. ${ }^{46}$ The $\Delta \mathrm{Gp}$ (del Gp) values were calculated from the pour stream compositions listed in Table 4-3 and the common logarithms of the PCT response (in $\mathrm{g} / \mathrm{L}$ ) for each element are listed in Table 4-4. The PCT response for a given glass would be expected to fall on the solid straight line. The solid green squares ( $\bullet$ ) are the measured PCT values for the pour stream glass samples. All of the measured PCT values were within the confidence intervals indicating that the PCT results for the pour stream glass samples were predictable from the SME compositions by the THERMO ${ }^{\mathrm{TM}}$ models. Those results confirmed that the use of DWPF's product composition correlations adequately produced an acceptable waste form and demonstrated the redundancy of the pour stream sample characterization for SB1A through SB6. 
Table 4-4. Normalized Elemental Releases (g/L) Predicted for Macrobatch and SME Samples and Measured for Pour Stream Samples.

\begin{tabular}{|c|c|c|c|c|c|c|}
\hline $\begin{array}{l}\text { Macro } \\
\text { Batch }\end{array}$ & $\begin{array}{l}\text { Sludge } \\
\text { Batch }\end{array}$ & Sample & $\begin{array}{l}\mathrm{NL}_{\mathrm{B}} \\
(\mathrm{g} / \mathrm{L})\end{array}$ & $\begin{array}{l}N_{L i} \\
(\mathrm{~g} / \mathrm{L})\end{array}$ & $\begin{array}{l}N L_{N a} \\
(\mathrm{~g} / \mathrm{L})\end{array}$ & Source \\
\hline \multirow[t]{4}{*}{ MB1 } & SB1A & MB Predicted & 0.61 & 0.66 & 0.61 & 34 \\
\hline & & SME (average of 5) & 0.74 & 0.77 & 0.74 & 47 \\
\hline & & SME 19-93 & 0.67 & 0.72 & 0.67 & 34 \\
\hline & & Pour Stream (average of 5) & 0.89 & 0.88 & 0.86 & $9,48-51$ \\
\hline \multirow[t]{4}{*}{ MB2 } & SB1B & MB Predicted & 0.37 & 0.44 & 0.38 & 35 \\
\hline & & SME 123 & 0.45 & 0.52 & 0.46 & 35 \\
\hline & & SME 94-207 & 0.40 & 0.47 & 0.41 & 35 \\
\hline & & Pour Stream S01142 & 0.63 & 0.78 & 0.59 & 13,14 \\
\hline \multirow[t]{4}{*}{ MB3 } & SB2 & MB Predicted & 0.53 & 0.59 & 0.54 & 36 \\
\hline & & SME 254 & 0.49 & 0.55 & 0.50 & 36 \\
\hline & & SME 208-271 & 0.58 & 0.63 & 0.59 & 36 \\
\hline & & Pour Stream S01913 & 1.18 & 1.10 & 1.11 & 37 \\
\hline \multirow[t]{4}{*}{ MB4 } & SB3 & MB Predicted & 0.64 & 0.69 & 0.65 & 38 \\
\hline & & SME 319 & 0.58 & 0.64 & 0.59 & 38 \\
\hline & & SME 272-401 & 0.69 & 0.73 & 0.69 & 38 \\
\hline & & Pour Stream S02312 & 1.09 & 1.03 & 0.94 & 20,39 \\
\hline \multirow[t]{4}{*}{ MB5 } & SB4 & MB Predicted & 0.42 & 0.49 & 0.44 & 40,52 \\
\hline & & SME 435 & 0.73 & 0.76 & 0.73 & 40,52 \\
\hline & & SME 402-467 & 0.45 & 0.52 & 0.46 & 40,52 \\
\hline & & Pour Stream & 0.67 & 0.76 & 0.71 & 25 \\
\hline \multirow[t]{4}{*}{ MB6 } & SB5 & MB Predicted & 0.78 & 0.81 & 0.78 & 42 \\
\hline & & SME 520 & 0.70 & 0.74 & 0.70 & 42 \\
\hline & & SME 468-530 & 0.86 & 0.87 & 0.85 & 42 \\
\hline & & Pour Stream S03317 & 0.72 & 0.88 & 0.81 & 25 \\
\hline \multirow[t]{5}{*}{ MB7 } & SB6 & MB Predicted & 0.82 & 0.84 & 0.81 & 43 \\
\hline & & SME 551 & 1.07 & 1.04 & 1.05 & 43 \\
\hline & & SME 531-569 & 0.91 & 0.91 & 0.90 & 43 \\
\hline & & Pour Stream S03472 & 0.69 & 0.81 & 0.85 & 32,44 \\
\hline & \multicolumn{2}{|c|}{ EA Benchmark Glass } & 16.7 & 9.6 & 13.3 & 53 \\
\hline
\end{tabular}
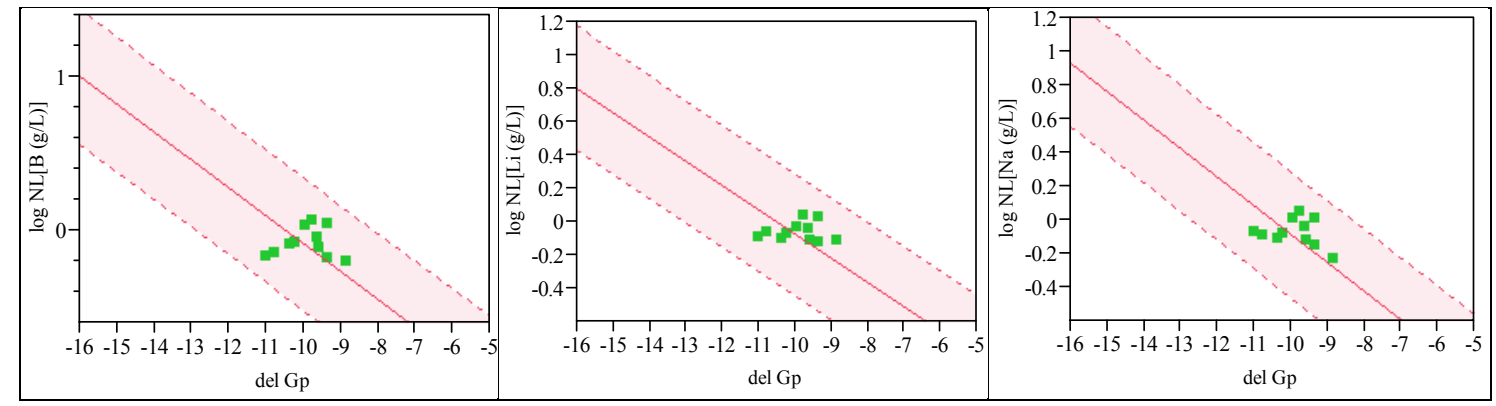

Figure 4-2. THERMO ${ }^{\text {TM }}$ Models with a 95\% Confidence Limit for an Individual PCT Measurement. 


\subsubsection{Reportable Radionuclides}

The reportable radionuclides are determined by analyzing a sludge slurry sample from the macrobatch termed the WAPS sample. The WAPS sample is taken from Tank 40 after all transfers have been made to the tank. The WAPS sample is extensively characterized for as many radionuclides as possible in order to determine the radionuclides meeting the criteria of WAPS Specification 1.2. ${ }^{6}$ (The chemical composition of the WAPS sample is also measured, providing an additional check on the reportable elements that were identified from the qualification sample for the sludge batch.) The majority of the radionuclide characterization must be performed by SRNL since DWPF does not have the capability to extensively characterize the potential radionuclides present in the glass. The DWPF measured Pu-238, U-238, Sr-90, and Cs-137 during SB1A and SB1B processing and confirmed that the characterization performed by SRNL was considered sufficient in determining the reportable radionuclides for the sludge to be processed through the DWPF. ${ }^{54}$ Once coupled operations began, the DWPF resumed measuring Cs-137 to inventory the additional Cs-137 received from auxiliary salt streams which is not present in the sludge WAPS sample. Likewise, Ti from the auxiliary ARP stream is currently measured in the SME and is used to inventory additional radionuclides received from that waste stream.

Table 4-5 through Table 4-12 list the WAPS reportable radionuclides for SB1A through SB6 determined from the sludge solids from the WAPS sample characterized by the SRNL. The concentrations in glass for radionuclides were transcribed from the SRNL pour stream reports except for the calculated concentrations of those radionuclides that were also measured. The calculated concentrations in glass for radionuclides that were measured were calculated using the sludge dilution factor (SDF) reported in the DWPF's records. The reason for this was to make a more appropriate comparison of the radionuclide concentration between that measured in the pour stream and that calculated from the sludge solids. All the radionuclides identified as reportable in the WAPS sample were verified in the pour stream samples. The measured concentrations of the radionuclides (identified as reportable) in the pour stream glasses were in good agreement with the expected concentrations calculated from the dried solids. ${ }^{\mathrm{m}}$ Those results confirmed that the DWPF's compliance strategy of measuring radionuclides in the WAPS sample adequately inventoried the reportable radionuclides in the waste form and demonstrated the redundancy of the pour stream sample characterization for SB1A through SB6.

\footnotetext{
${ }^{\mathrm{m}}$ Good agreement should be understood to mean "approximately the same order of magnitude". The error in the precision of those measurements is generally considered to be approximately $20 \%$. However, the error in the measurement value (accuracy) depends on several factors including volatilization and measurement interference. Furthermore, many radionuclides require difficult and complex separation steps to obtain an accurate measurement and cost can be a prohibitive factor in obtaining the most accurate measurement. Considering the measurement error, volatilization, and measurement interferences, a more reasonable approximation of the total error in a reported value can be taken to be $2-5$ times.
} 
Table 4-5. Reportable Radionuclides Measured in the Sludge and the Pour Stream Sample from Macrobatch 1 (SB1A)*

\begin{tabular}{|c|c|c|c|}
\hline \multicolumn{4}{|l|}{$\begin{array}{l}\text { Macrobatch } 1 \\
\text { SB1A }\end{array}$} \\
\hline \multirow[b]{2}{*}{ Radionuclide } & \multirow[b]{2}{*}{$\begin{array}{c}\text { Sludge } \\
\text { Measured }\end{array}$} & \multicolumn{2}{|r|}{ Glass } \\
\hline & & $\begin{array}{l}\text { Calculated }^{i} \\
\text { SDF }=2.87\end{array}$ & $\begin{array}{c}\text { Measured } \\
\text { Pour Stream S00834 }\end{array}$ \\
\hline & $\mathrm{Ci} / \mathrm{kg}$ & $\mathrm{Ci} / \mathrm{kg}$ & $\mathrm{Ci} / \mathrm{kg}$ \\
\hline Am-241 & $6.20 \mathrm{E}-03$ & $2.16 \mathrm{E}-03$ & $2.40 \mathrm{E}-03$ \\
\hline Am-243 & $3.80 \mathrm{E}-05$ & $1.32 \mathrm{E}-05$ & $2.40 \mathrm{E}-05$ \\
\hline $\mathrm{Cm}-244$ & $1.20 \mathrm{E}-02$ & $4.18 \mathrm{E}-03$ & 2.80E-03 \\
\hline $\mathrm{Cm}-245$ & $5.70 \mathrm{E}-07$ & $1.99 \mathrm{E}-07$ & n.m. \\
\hline $\mathrm{Cm}-246$ & 5.50E-06 & $1.92 \mathrm{E}-06$ & n.m. \\
\hline Cs-137 & $6.30 \mathrm{E}-02$ & $2.20 \mathrm{E}-02$ & 2.10E-02 \\
\hline $\mathrm{Nb}-93 \mathrm{~m}$ & 4.20E-05 & $1.46 \mathrm{E}-05$ & n.m. \\
\hline $\mathrm{Ni}-59$ & $1.90 \mathrm{E}-05$ & $6.62 \mathrm{E}-06$ & n.m. \\
\hline $\mathrm{Ni}-63$ & 3.70E-03 & $1.29 \mathrm{E}-03$ & n.m. \\
\hline Np-237 & $1.40 \mathrm{E}-05$ & $4.88 \mathrm{E}-06$ & 5.10E-06 \\
\hline Pu-238 & $1.40 \mathrm{E}-01$ & $4.88 \mathrm{E}-02$ & 2.90E-02 \\
\hline Pu-239 & $6.80 \mathrm{E}-03$ & $2.37 \mathrm{E}-03$ & 1.90E-03 \\
\hline Pu-240 & $1.80 \mathrm{E}-03$ & $6.27 \mathrm{E}-04$ & $6.80 \mathrm{E}-04$ \\
\hline Pu-241 & $3.20 \mathrm{E}-02$ & $1.11 \mathrm{E}-02$ & 1.00E-02 \\
\hline Pu-242 & $1.60 \mathrm{E}-06$ & 5.57E-07 & 1.30E-06 \\
\hline Se-79 & 1.10E-05 & $3.83 \mathrm{E}-06$ & n.m. \\
\hline Sm-151 & $1.20 \mathrm{E}-02$ & $4.18 \mathrm{E}-03$ & 6.60E-03 \\
\hline Sn-126 & $6.50 \mathrm{E}-06$ & $2.26 \mathrm{E}-06$ & n.m. \\
\hline Sr-90 & $6.10 \mathrm{E}-01$ & 2.13E-01 & 2.00E-01 \\
\hline Tc-99 & $2.20 \mathrm{E}-04$ & 7.67E-05 & 8.00E-05 \\
\hline Th-229 & $1.30 \mathrm{E}-07$ & $4.53 \mathrm{E}-08$ & n.m. \\
\hline U-233 & $2.60 \mathrm{E}-05$ & $9.06 \mathrm{E}-06$ & $1.10 \mathrm{E}-05$ \\
\hline U-234 & $2.60 \mathrm{E}-05$ & $9.06 \mathrm{E}-06$ & $9.40 \mathrm{E}-06$ \\
\hline U-235 & $3.50 \mathrm{E}-07$ & $1.22 \mathrm{E}-07$ & 1.10E-07 \\
\hline U-236 & $8.40 \mathrm{E}-07$ & 2.93E-07 & $2.80 \mathrm{E}-07$ \\
\hline U-238 & $1.10 \mathrm{E}-05$ & $3.83 E-06$ & 2.90E-06 \\
\hline Zr-93 & 5.30E-05 & $1.85 \mathrm{E}-05$ & 2.00E-05 \\
\hline Source & 8,10 & 8 & 3,9 \\
\hline
\end{tabular}

${ }^{*}$ Values in this Table are the measured values transcribed from those reported in the source(s) if not otherwise indicated. WAPS specification 1.2 requires the inventory of radionuclides that have half-lives longer than 10 years and contribute $>0.05 \%$ of the total Curie inventory indexed to the years 2015 and 3115 . (n.m. $=$ not measured)

${ }^{\mathrm{i}}$ The calculated values for radionuclides were obtained by dividing the sludge concentration by the SDF 2.87. 
SRNL-STI-2012-00157

Revision 0

Table 4-6. Reportable Radionuclides Measured in the Sludge and the Pour Stream Sample from Macrobatch 2 (SB1B)

\begin{tabular}{|c|c|c|c|}
\hline \multicolumn{4}{|l|}{$\begin{array}{l}\text { Macrobatch } 2 \\
\text { SB1B }\end{array}$} \\
\hline \multirow{3}{*}{ Radionuclide } & \multirow{3}{*}{$\begin{array}{c}\text { Sludge } \\
\text { Measured }\end{array}$} & \multicolumn{2}{|r|}{ Glass } \\
\hline & & Calculated $^{i}$ & Measured \\
\hline & & $\mathrm{SDF}=2.62$ & Pour Stream S01142 \\
\hline & $\mathrm{Ci} / \mathrm{kg}$ & $\mathrm{Ci} / \mathrm{kg}$ & $\mathrm{Ci} / \mathrm{kg}$ \\
\hline Am-241 & $6.65 \mathrm{E}-03$ & $2.54 \mathrm{E}-03$ & $2.30 \mathrm{E}-03$ \\
\hline Am-243 & $5.65 \mathrm{E}-05$ & $2.16 \mathrm{E}-05$ & $2.00 \mathrm{E}-05$ \\
\hline$C-14^{\mathrm{ii}}$ & $4.41 \mathrm{E}-06$ & $1.68 \mathrm{E}-06$ & $<7.4 \mathrm{E}-08$ \\
\hline $\mathrm{Cm}-244$ & 4.43E-03 & 1.69E-03 & $2.50 \mathrm{E}-03$ \\
\hline $\mathrm{Cm}-246$ & 4.05E-05 & $1.55 \mathrm{E}-05$ & $1.60 \mathrm{E}-05$ \\
\hline Cs-137 & $1.59 \mathrm{E}-01$ & 6.07E-02 & $5.00 \mathrm{E}-02$ \\
\hline$I-129^{i i}$ & 1.09E-06 & 4.16E-07 & 4.10E-08 \\
\hline $\mathrm{Nb}-93 \mathrm{~m}$ & $6.55 \mathrm{E}-05$ & $2.50 \mathrm{E}-05$ & n.m. \\
\hline Ni-59 & 4.78E-05 & $1.82 \mathrm{E}-05$ & n.m. \\
\hline $\mathrm{Ni}-63$ & $8.42 \mathrm{E}-03$ & $3.21 \mathrm{E}-03$ & n.m. \\
\hline Np-237 & 1.29E-05 & $4.92 \mathrm{E}-06$ & $5.90 \mathrm{E}-06$ \\
\hline Pu-238 & $9.95 \mathrm{E}-02$ & $3.80 \mathrm{E}-02$ & $3.30 \mathrm{E}-02$ \\
\hline Pu-239 & 4.89E-03 & $1.87 \mathrm{E}-03$ & $1.90 \mathrm{E}-03$ \\
\hline Pu-240 & $1.78 \mathrm{E}-03$ & 6.79E-04 & $6.60 \mathrm{E}-04$ \\
\hline Pu-241 & $2.84 \mathrm{E}-02$ & $1.08 \mathrm{E}-02$ & $1.60 \mathrm{E}-02$ \\
\hline Pu-242 & 3.73E-06 & $1.42 \mathrm{E}-06$ & $1.10 \mathrm{E}-06$ \\
\hline Se-79 & $<4.16 \mathrm{E}-05$ & $<1.6 \mathrm{E}-05$ & n.m. \\
\hline Sm-151 & $6.32 \mathrm{E}-02$ & $2.41 \mathrm{E}-02$ & $2.10 \mathrm{E}-02$ \\
\hline Sn-121m & $1.27 \mathrm{E}-03$ & $<4.8 \mathrm{E}-04$ & n.m. \\
\hline Sn-126 iv & $<1.42 \mathrm{E}-05$ & $<3.0 \mathrm{E}-06$ & n.m. \\
\hline Sr-90 & $4.24 \mathrm{E}+00$ & $1.62 \mathrm{E}+00$ & $1.40 \mathrm{E}+00$ \\
\hline Tc-99 & $1.88 \mathrm{E}-04$ & $7.18 \mathrm{E}-05$ & $7.00 \mathrm{E}-05$ \\
\hline Th-229 & 6.57E-08 & $2.51 \mathrm{E}-08$ & n.m. \\
\hline U-233 & 4.35E-05 & $1.66 \mathrm{E}-05$ & $1.70 \mathrm{E}-05$ \\
\hline U-234 & 2.89E-05 & 1.10E-05 & $1.30 \mathrm{E}-05$ \\
\hline U-235 & 2.81E-07 & $1.07 \mathrm{E}-07$ & $1.20 \mathrm{E}-07$ \\
\hline U-236 & $7.38 \mathrm{E}-07$ & $2.82 \mathrm{E}-07$ & 4.10E-07 \\
\hline$U-238$ & $6.46 \mathrm{E}-06$ & $2.47 \mathrm{E}-06$ & $3.00 \mathrm{E}-06$ \\
\hline Zr-93 & $8.22 \mathrm{E}-05$ & $3.14 \mathrm{E}-05$ & $1.00 \mathrm{E}-04$ \\
\hline Source & 11,12 & 12 & $3,13,55$ \\
\hline
\end{tabular}

*Values in this Table are the measured values transcribed from those reported in the source(s) if not otherwise indicated. WAPS specification 1.2 requires the inventory of radionuclides that have half-lives longer than 10 years and contribute $>0.05 \%$ of the total Curie inventory indexed to the years 2015 and 3115 . (n.m. $=$ not measured)

${ }^{\mathrm{i}}$ The calculated values for radionuclides were obtained by dividing the sludge concentration by the SDF 2.62.

${ }^{\mathrm{ii}} \mathrm{C}-14$ and I-129 were identified as being reportable in the sludge analysis; however, C-14 and I-129 did not meet the reporting requirements due to volatilization at the DWPF.

${ }^{\text {iii }}$ Several revisions were made to reports associated with SB1B. There are several reported concentrations for Sn-126 in the sludge and glass that appeared to result from rounding error. The sludge value was taken from the DWPF production records, the greatest reported concentration. The concentration in glass was calculated using the SDF which encompasses (greater than) the reported values in the pour stream reports. 
Table 4-7. Reportable Radionuclides Measured in the Sludge and the Pour Stream Sample from Macrobatch 3 (SB2)*

\begin{tabular}{|c|c|c|c|}
\hline $\begin{array}{l}\text { Macrobatch } 3 \\
\text { SB2 }\end{array}$ & & & \\
\hline \multirow[b]{2}{*}{ Radionuclide } & \multirow[b]{2}{*}{$\begin{array}{l}\text { Sludge } \\
\text { Measured }\end{array}$} & \multicolumn{2}{|r|}{ Glass } \\
\hline & & $\begin{array}{l}\text { Calculated }^{i} \\
\text { SDF }=2.49\end{array}$ & $\begin{array}{c}\text { Measured } \\
\text { Pour Stream S01913 }\end{array}$ \\
\hline & $\mathrm{Ci} / \mathrm{kg}$ & $\mathrm{Ci} / \mathrm{kg}$ & $\mathrm{Ci} / \mathrm{kg}$ \\
\hline Am-241 & $3.27 \mathrm{E}-02$ & $1.31 \mathrm{E}-02$ & $1.03 E-02$ \\
\hline Am-243 & 5.34E-04 & $2.14 \mathrm{E}-04$ & $1.92 \mathrm{E}-04$ \\
\hline Cf-251 & 1.19E-05 & 4.78E-06 & n.m. \\
\hline $\mathrm{Cm}-244$ & $4.42 \mathrm{E}-02$ & $1.78 \mathrm{E}-02$ & n.m. \\
\hline $\mathrm{Cm}-245$ & $3.86 \mathrm{E}-06$ & $1.55 \mathrm{E}-06$ & n.m. \\
\hline $\mathrm{Cm}-246$ & $2.48 \mathrm{E}-05$ & $9.96 \mathrm{E}-06$ & n.m. \\
\hline Cs-137 & 2.75E-01 & $1.10 \mathrm{E}-01$ & 8.64E-02 \\
\hline $\mathrm{Ni}-59$ & $3.13 \mathrm{E}-04$ & $1.26 \mathrm{E}-04$ & n.m. \\
\hline $\mathrm{Ni}-63$ & $2.05 \mathrm{E}-02$ & 8.23E-03 & n.m. \\
\hline Np-237 & $1.33 \mathrm{E}-05$ & $5.34 \mathrm{E}-06$ & $5.74 \mathrm{E}-06$ \\
\hline Pu-238 & $3.85 \mathrm{E}-02$ & $1.55 \mathrm{E}-02$ & $1.24 \mathrm{E}-02$ \\
\hline Pu-239 & $7.68 \mathrm{E}-03$ & $3.08 \mathrm{E}-03$ & $4.02 \mathrm{E}-03$ \\
\hline Pu-240 & $2.38 \mathrm{E}-03$ & $9.56 \mathrm{E}-04$ & 1.27E-03 \\
\hline Pu-241 & $2.80 \mathrm{E}-02$ & $1.12 \mathrm{E}-02$ & $8.48 \mathrm{E}-03$ \\
\hline Pu-242 & 4.59E-06 & $1.84 \mathrm{E}-06$ & 3.01E-06 \\
\hline Se-79 & $6.23 \mathrm{E}-05$ & $2.50 \mathrm{E}-05$ & n.m. \\
\hline Sm-151 & 1.77E-01 & $7.11 \mathrm{E}-02$ & $6.95 \mathrm{E}-02$ \\
\hline Sn-121m & $3.64 \mathrm{E}-03$ & $1.46 \mathrm{E}-03$ & n.m. \\
\hline Sn-126 & 4.49E-05 & $1.80 \mathrm{E}-05$ & n.m. \\
\hline Sr-90 & $4.52 E+00$ & $1.82 \mathrm{E}+00$ & $1.47 \mathrm{E}+00$ \\
\hline Tc-99 & $1.26 \mathrm{E}-04$ & $5.06 \mathrm{E}-05$ & 4.63E-05 \\
\hline$U-233$ & $1.07 \mathrm{E}-05$ & 4.30E-06 & $5.12 \mathrm{E}-06$ \\
\hline U-234 & 3.57E-05 & $1.43 \mathrm{E}-05$ & $1.64 \mathrm{E}-05$ \\
\hline$U-235$ & $6.57 \mathrm{E}-07$ & $2.64 \mathrm{E}-07$ & $2.96 \mathrm{E}-07$ \\
\hline U-236 & $9.44 \mathrm{E}-07$ & $3.79 E-07$ & 4.53E-07 \\
\hline U-238 & $2.53 \mathrm{E}-05$ & $1.02 \mathrm{E}-05$ & $9.65 \mathrm{E}-06$ \\
\hline Zr-93 & $1.36 \mathrm{E}-04$ & $5.46 \mathrm{E}-05$ & $1.51 \mathrm{E}-04$ \\
\hline Source & 16,17 & 16 & 3,16 \\
\hline
\end{tabular}

${ }^{*}$ Values in this Table are the measured values transcribed from those reported in the source(s) if not otherwise indicated. WAPS specification 1.2 requires the inventory of radionuclides that have half-lives longer than 10 years and contribute $>0.05 \%$ of the total Curie inventory indexed to the years 2015 and 3115 . (n.m. = not measured)

${ }^{\mathrm{i}}$ The calculated values for radionuclides were obtained by dividing the sludge concentration by the SDF 2.49. 
Table 4-8. Reportable Radionuclides Measured in the Sludge and the Pour Stream Sample from Macrobatch 4 (SB3).

\begin{tabular}{|c|c|c|c|}
\hline \multicolumn{4}{|l|}{$\begin{array}{l}\text { Macrobatch } 4 \\
\text { SB3 }\end{array}$} \\
\hline \multirow[b]{2}{*}{ Radionuclide } & \multirow[b]{2}{*}{$\begin{array}{l}\text { Sludge } \\
\text { Measured }\end{array}$} & \multicolumn{2}{|r|}{ Glass } \\
\hline & & $\begin{array}{l}\text { Calculated }^{\mathrm{i}} \\
\mathrm{SDF}=2.09\end{array}$ & $\begin{array}{c}\text { Measured } \\
\text { Pour Stream S02312 }\end{array}$ \\
\hline & $\mathrm{Ci} / \mathrm{kg}$ & $\mathrm{Ci} / \mathrm{kg}$ & $\mathrm{Ci} / \mathrm{kg}$ \\
\hline Am-241 & $1.85 \mathrm{E}-02$ & $8.85 \mathrm{E}-03$ & $7.86 \mathrm{E}-03$ \\
\hline$A m-242 m$ & $<8.93 \mathrm{E}-05$ & $<4.27 \mathrm{E}-05$ & n.m. \\
\hline Am-243 & $1.55 \mathrm{E}-03$ & $7.42 \mathrm{E}-04$ & 7.53E-04 \\
\hline Cf-249 & $<2.83 \mathrm{E}-05$ & $<1.35 \mathrm{E}-05$ & n.m. \\
\hline Cf-251 & $<2.24 \mathrm{E}-05$ & $<1.07 E-05$ & n.m. \\
\hline $\mathrm{Cm}-244$ & 7.00E-02 & $3.35 \mathrm{E}-02$ & n.m. \\
\hline $\mathrm{Cm}-245$ & $1.09 \mathrm{E}-05$ & $5.22 \mathrm{E}-06$ & n.m. \\
\hline $\mathrm{Cm}-246$ & $1.62 \mathrm{E}-05$ & $7.75 \mathrm{E}-06$ & n.m. \\
\hline $\mathrm{Cm}-247$ & $<2.65 \mathrm{E}-05$ & $<1.27 \mathrm{E}-05$ & n.m. \\
\hline $\mathrm{Cm}-248$ & $<2.77 \mathrm{E}-05$ & $<1.33 \mathrm{E}-05$ & n.m. \\
\hline Cs-137 & 3.15E-01 & $1.51 \mathrm{E}-01$ & $1.45 \mathrm{E}-01$ \\
\hline $\mathrm{Ni}-59$ & $6.63 \mathrm{E}-04$ & 3.17E-04 & n.m. \\
\hline $\mathrm{Ni}-63$ & 5.41E-02 & $2.59 \mathrm{E}-02$ & n.m. \\
\hline Np-237 & 3.30E-05 & $1.58 \mathrm{E}-05$ & n.m. \\
\hline Pu-238 & $2.59 \mathrm{E}-02$ & $1.24 \mathrm{E}-02$ & $1.32 \mathrm{E}-02$ \\
\hline Pu-239 & $1.37 \mathrm{E}-02$ & $6.56 \mathrm{E}-03$ & $7.55 \mathrm{E}-03$ \\
\hline Pu-240 & 4.80E-03 & $2.30 \mathrm{E}-03$ & $2.40 \mathrm{E}-03$ \\
\hline Pu-241 & $5.42 \mathrm{E}-02$ & $2.59 \mathrm{E}-02$ & $2.83 \mathrm{E}-02$ \\
\hline Pu-242 & $5.46 \mathrm{E}-06$ & $2.61 \mathrm{E}-06$ & $1.72 \mathrm{E}-06$ \\
\hline Se-79 & $<1.97 \mathrm{E}-05$ & $<9.42 \mathrm{E}-06$ & n.m. \\
\hline Sm-151 & $1.96 \mathrm{E}-01$ & $9.38 \mathrm{E}-02$ & 8.89E-02 \\
\hline Sn-121m & $2.34 \mathrm{E}-03$ & $1.12 \mathrm{E}-03$ & n.m. \\
\hline Sn-126 & $1.42 \mathrm{E}-05$ & $6.79 \mathrm{E}-06$ & n.m. \\
\hline Sr-90 & $4.85 \mathrm{E}+00$ & $2.32 \mathrm{E}+00$ & $1.89 \mathrm{E}+00$ \\
\hline Tc-99 & $1.96 \mathrm{E}-04$ & $9.38 \mathrm{E}-05$ & $5.92 \mathrm{E}-05$ \\
\hline U-233 & $1.56 \mathrm{E}-05$ & $7.46 \mathrm{E}-06$ & 4.30E-06 \\
\hline U-234 & 3.03E-05 & $1.45 \mathrm{E}-05$ & $1.35 \mathrm{E}-05$ \\
\hline U-235 & $7.29 \mathrm{E}-07$ & $3.49 E-07$ & 3.66E-07 \\
\hline U-236 & $8.46 \mathrm{E}-07$ & 4.05E-07 & 4.16E-07 \\
\hline U-238 & $2.26 \mathrm{E}-05$ & $1.08 \mathrm{E}-05$ & $9.94 \mathrm{E}-06$ \\
\hline Zr-93 & 4.43E-05 & $2.12 \mathrm{E}-05$ & $2.13 \mathrm{E}-04$ \\
\hline Source & 20,21 & 20 & 3,20 \\
\hline
\end{tabular}

*Values in this Table are the measured values transcribed from those reported in the source(s) if not otherwise indicated. WAPS specification 1.2 requires the inventory of radionuclides that have half-lives longer than 10 years and contribute $>0.05 \%$ of the total Curie inventory indexed to the years 2015 and 3115 . (n.m. $=$ not measured)

${ }^{\mathrm{i}}$ The calculated values for radionuclides were obtained by dividing the sludge concentration by the SDF 2.09. 
Table 4-9. Reportable Radionuclides Measured in the Sludge and the Pour Stream Sample from Macrobatch 5 (SB4).

\begin{tabular}{|c|c|c|c|}
\hline \multicolumn{4}{|l|}{$\begin{array}{l}\text { Macrobatch } 5 \\
\text { SB4 }\end{array}$} \\
\hline \multirow{3}{*}{ Radionuclide } & \multirow[b]{2}{*}{$\begin{array}{l}\text { Sludge } \\
\text { Measured }\end{array}$} & \multicolumn{2}{|r|}{ Glass } \\
\hline & & $\begin{array}{l}\text { Calculated } \\
\text { SDF }=2.21\end{array}$ & $\begin{array}{c}\text { Measured } \\
\text { Pour Stream S02902 }\end{array}$ \\
\hline & $\mathrm{Ci} / \mathrm{kg}$ & $\mathrm{Ci} / \mathrm{kg}$ & $\mathrm{Ci} / \mathrm{kg}$ \\
\hline Am-241 & $1.76 \mathrm{E}-02$ & $7.96 \mathrm{E}-03$ & $7.66 \mathrm{E}-03$ \\
\hline$A m-242 m$ & $7.00 \mathrm{E}-05$ & 3.17E-05 & n.m. \\
\hline Am-243 & $1.64 \mathrm{E}-03$ & 7.42E-04 & n.m. \\
\hline Bk-247 & $<1.36 \mathrm{E}-05$ & $<6.15 \mathrm{E}-05$ & n.m. \\
\hline Cf-251 & $<1.88 \mathrm{E}-05$ & $<8.51 \mathrm{E}-06$ & n.m. \\
\hline $\mathrm{Cm}-244$ & 9.07E-02 & 4.10E-02 & n.m. \\
\hline $\mathrm{Cm}-245$ & $<3.49 \mathrm{E}-05$ & $<1.38 \mathrm{E}-05$ & n.m. \\
\hline $\mathrm{Cm}-246$ & 1.90E-05 & $8.60 \mathrm{E}-06$ & n.m. \\
\hline $\mathrm{Cm}-247$ & $<5.65 \mathrm{E}-06$ & $<2.56 \mathrm{E}-06$ & n.m. \\
\hline $\mathrm{Cm}-248$ & $<5.91 \mathrm{E}-06$ & $<2.67 \mathrm{E}-06$ & n.m. \\
\hline Cs-137 & $2.49 \mathrm{E}-01$ & 1.13E-01 & $1.03 \mathrm{E}-01$ \\
\hline $\mathrm{Nb}-93 \mathrm{~m}$ & 2.09E-04 & $9.46 \mathrm{E}-05$ & n.m. \\
\hline $\mathrm{Ni}-59$ & 5.67E-04 & 2.57E-04 & n.m. \\
\hline $\mathrm{Ni}-63$ & $6.58 \mathrm{E}-02$ & $2.98 \mathrm{E}-02$ & n.m. \\
\hline Np-237 & 2.60E-05 & $1.18 \mathrm{E}-05$ & $9.33 \mathrm{E}-06$ \\
\hline Pu-238 & $1.22 \mathrm{E}-01$ & $5.52 \mathrm{E}-02$ & $3.78 \mathrm{E}-02$ \\
\hline Pu-239 & $1.03 \mathrm{E}-02$ & 4.66E-03 & $4.45 \mathrm{E}-03$ \\
\hline Pu-240 & 4.51E-03 & 2.04E-03 & $1.87 \mathrm{E}-03$ \\
\hline Pu-241 & $1.08 \mathrm{E}-01$ & 4.89E-02 & $<1.27 \mathrm{E}-02$ \\
\hline Pu-242 & 5.83E-06 & 2.64E-06 & $<1.60$ E-05 \\
\hline Se-79 & $1.61 \mathrm{E}-05$ & $7.29 E-06$ & n.m. \\
\hline Sm-151 & $1.13 \mathrm{E}-01$ & 5.11E-02 & n.m. \\
\hline Sn-126 & $<3.24 \mathrm{E}-04$ & $<1.47 \mathrm{E}-04$ & n.m. \\
\hline Sr-90 & $7.23 E+00$ & $3.27 E+00$ & $2.85 E+00$ \\
\hline Tc-99 & $1.41 \mathrm{E}-04$ & $6.38 \mathrm{E}-05$ & $<5.51 \mathrm{E}-05$ \\
\hline U-233 & $<1.91 \mathrm{E}-05$ & $<8.64 \mathrm{E}-06$ & $<2.36 \mathrm{E}-05$ \\
\hline U-234 & $3.40 \mathrm{E}-05$ & $1.54 \mathrm{E}-05$ & $1.64 \mathrm{E}-05$ \\
\hline U-235 & $6.41 \mathrm{E}-07$ & $2.90 \mathrm{E}-07$ & $2.41 \mathrm{E}-07$ \\
\hline U-236 & $8.12 \mathrm{E}-07$ & 3.67E-07 & 3.27E-07 \\
\hline U-238 & $1.77 \mathrm{E}-05$ & 8.01E-06 & $6.36 \mathrm{E}-06$ \\
\hline Zr-93 & $2.64 \mathrm{E}-04$ & 1.19E-04 & $1.76 \mathrm{E}-04$ \\
\hline Source & $23-25$ & 24 & 25 \\
\hline
\end{tabular}

"Values in this Table are the measured values transcribed from those reported in the source(s) if not otherwise indicated. WAPS specification 1.2 requires the inventory of radionuclides that have half-lives longer than 10 years and contribute $>0.05 \%$ of the total Curie inventory indexed to the years 2015 and 3115. (n.m. $=$ not measured)

${ }^{\mathrm{i}}$ The calculated values for radionuclides were obtained by dividing the sludge concentration by the SDF 2.21. 
Table 4-10. Reportable Radionuclides Measured in the Sludge and the Pour Stream Sample from Macrobatch 6 (SB5).

\begin{tabular}{|c|c|c|c|}
\hline \multicolumn{4}{|l|}{$\begin{array}{l}\text { Macrobatch } 6 \\
\text { SB5 }\end{array}$} \\
\hline \multirow[b]{2}{*}{ Radionuclide } & \multirow[b]{2}{*}{$\begin{array}{l}\text { Sludge } \\
\text { Measured }\end{array}$} & \multicolumn{2}{|r|}{ Glass } \\
\hline & & $\begin{array}{l}\text { Calculated } \\
\text { SDF }=2.49\end{array}$ & $\begin{array}{c}\text { Measured } \\
\text { Pour Stream S03317 }\end{array}$ \\
\hline & $\mathrm{Ci} / \mathrm{kg}$ & $\mathrm{Ci} / \mathrm{kg}$ & $\mathrm{Ci} / \mathrm{kg}$ \\
\hline Am-241 & $3.25 \mathrm{E}-02$ & $1.31 \mathrm{E}-02$ & $1.06 \mathrm{E}-02$ \\
\hline$A m-242 m$ & $<4.54 \mathrm{E}-04$ & $<1.75 \mathrm{E}-04$ & n.m. \\
\hline Am-243 & $9.64 \mathrm{E}-04$ & 3.87E-04 & n.m. \\
\hline Cf-251 & $<2.31 \mathrm{E}-05$ & $<9.28 \mathrm{E}-06$ & n.m. \\
\hline $\mathrm{Cl}-36$ & $<9.75 E-04$ & $<3.92 \mathrm{E}-04$ & n.m. \\
\hline $\mathrm{Cm}-244$ & $4.61 \mathrm{E}-02$ & $1.85 \mathrm{E}-02$ & n.m. \\
\hline $\mathrm{Cm}-245$ & $<4.29 \mathrm{E}-04$ & $<1.72 \mathrm{E}-04$ & n.m. \\
\hline $\mathrm{Cm}-246$ & $1.29 \mathrm{E}-05$ & 5.18E-06 & n.m. \\
\hline Ce-144 & $<7.22 \mathrm{E}-04$ & $<2.90 \mathrm{E}-04$ & n.m. \\
\hline Cs-134 & $<8.86 \mathrm{E}-04$ & $<3.56 \mathrm{E}-04$ & n.m. \\
\hline Cs-137 & 3.23E-01 & $\begin{array}{r}1.30 \mathrm{E}-01 \\
{ }^{\mathrm{ii}} 1.45 \mathrm{E}-01\end{array}$ & 1.67E-01 \\
\hline $\mathrm{Nb}-93 \mathrm{~m}$ & 3.93E-04 & $1.58 \mathrm{E}-04$ & n.m. \\
\hline $\mathrm{Ni}-59$ & $1.30 \mathrm{E}-03$ & $5.22 \mathrm{E}-04$ & n.m. \\
\hline $\mathrm{Ni}-63$ & 1.11E-01 & 4.46E-02 & n.m. \\
\hline Np-237 & $6.92 \mathrm{E}-05$ & $2.78 \mathrm{E}-05$ & $1.91 \mathrm{E}-05$ \\
\hline Pm-147 & $<7.22 \mathrm{E}-04$ & $<2.90 \mathrm{E}-04$ & n.m. \\
\hline Pu-238 & 2.76E-01 & 1.11E-01 & $1.66 \mathrm{E}-01$ \\
\hline Pu-239 & $2.04 \mathrm{E}-02$ & 8.19E-03 & $6.69 \mathrm{E}-03$ \\
\hline Pu-240 & $6.59 \mathrm{E}-03$ & $2.65 \mathrm{E}-03$ & $2.06 \mathrm{E}-03$ \\
\hline Pu-241 & $9.74 \mathrm{E}-02$ & 3.91E-02 & $3.49 \mathrm{E}-02$ \\
\hline Pu-242 & $6.82 \mathrm{E}-06$ & $2.74 \mathrm{E}-06$ & $<1.58 \mathrm{E}-05$ \\
\hline Rh-106 & $<3.13 \mathrm{E}-04$ & $<1.26 \mathrm{E}-04$ & n.m. \\
\hline Ru-106 & $<3.13 \mathrm{E}-04$ & $<1.26 \mathrm{E}-04$ & n.m. \\
\hline Sm-151 & $1.82 \mathrm{E}-01$ & 7.31E-02 & n.m. \\
\hline Sn-126 & $<3.60 \mathrm{E}-04$ & $<1.38 \mathrm{E}-04$ & n.m. \\
\hline Sr-90 & $2.25 \mathrm{E}+01$ & $9.04 \mathrm{E}+00$ & $5.03 \mathrm{E}+00$ \\
\hline Tc-99 & $1.53 \mathrm{E}-04$ & $6.14 \mathrm{E}-05$ & 4.74E-05 \\
\hline U-233 & $2.22 \mathrm{E}-05$ & $8.92 \mathrm{E}-06$ & $<1.56 \mathrm{E}-05$ \\
\hline U-234 & $6.15 \mathrm{E}-05$ & 2.47E-05 & $2.38 \mathrm{E}-05$ \\
\hline U-235 & 7.00E-07 & $2.81 \mathrm{E}-07$ & $2.79 \mathrm{E}-07$ \\
\hline U-236 & $1.34 \mathrm{E}-06$ & $5.38 \mathrm{E}-07$ & $5.29 E-07$ \\
\hline U-238 & 1.67E-05 & $6.71 \mathrm{E}-06$ & $6.37 \mathrm{E}-06$ \\
\hline Zr-93 & $5.23 \mathrm{E}-04$ & $2.10 \mathrm{E}-04$ & $3.53 \mathrm{E}-04$ \\
\hline Source & 25,28 & 25 & 25 \\
\hline
\end{tabular}

${ }^{*}$ Values in this Table are the measured values transcribed from those reported in the source(s) if not otherwise indicated. WAPS specification 1.2 requires the inventory of radionuclides that have half-lives longer than 10 years and contribute $>0.05 \%$ of the total Curie inventory indexed to the years 2015 and 3115. (n.m. $=$ not measured)

${ }^{\mathrm{i}}$ The calculated values for radionuclides were obtained by dividing the sludge concentration by the SDF 2.21.

${ }^{\text {ii }}$ Measured Cs-137 concentration from the DWPF Production Inputs for SME batch 520 (see Table 4-2). 
Table 4-11. Reportable Radionuclides Measured in the Sludge and the Pour Stream Sample from Macrobatch 7 (SB6).

\begin{tabular}{|c|c|c|c|}
\hline $\begin{array}{l}\text { Macrobatch } 7 \\
\text { SB6 }\end{array}$ & & & \\
\hline \multirow[t]{2}{*}{ Radionuclide } & $\begin{array}{c}\text { Sludge } \\
\text { Measured }\end{array}$ & $\begin{array}{l}\text { Calculated }^{i} \\
\text { SDF }=2.35\end{array}$ & $\begin{array}{c}\text { Measured } \\
\text { Pour Stream S03472 }\end{array}$ \\
\hline & $\mathrm{Ci} / \mathrm{kg}$ & $\mathrm{Ci} / \mathrm{kg}$ & $\mathrm{Ci} / \mathrm{kg}$ \\
\hline Am-241 & $3.3 \mathrm{E}-02$ & $1.4 \mathrm{E}-02$ & $1.4 \mathrm{E}-02$ \\
\hline$A m-242 m$ & $2.3 \mathrm{E}-04$ & $9.8 \mathrm{E}-05$ & n.m. \\
\hline Am-243 & 4.3E-03 & $1.8 \mathrm{E}-03$ & n.m. \\
\hline Cf-249 & $<2.3 \mathrm{E}-05$ & $<9.8 \mathrm{E}-06$ & n.m. \\
\hline Cf-251 & $<5.5 E-05$ & $<2.3 \mathrm{E}-05$ & n.m. \\
\hline $\mathrm{Cm}-244$ & $1.5 \mathrm{E}-01$ & $6.4 \mathrm{E}-02$ & n.m. \\
\hline $\mathrm{Cm}-245$ & $2.0 \mathrm{E}-05$ & $8.5 \mathrm{E}-06$ & n.m. \\
\hline $\mathrm{Cm}-246$ & $6.5 \mathrm{E}-05$ & $2.8 \mathrm{E}-05$ & n.m. \\
\hline $\mathrm{Cm}-248$ & $<7.1 \mathrm{E}-06$ & $<3.0 \mathrm{E}-06$ & n.m. \\
\hline Cs-137i & $3.9 \mathrm{E}-01$ & $\begin{array}{r}1.7 \mathrm{E}-01 \\
\text { iii } 1.7 \mathrm{E}+00\end{array}$ & $1.3 \mathrm{E}+00$ \\
\hline $\mathrm{Nb}-93 \mathrm{~m}$ & $3.8 \mathrm{E}-04$ & 1.6E-04 & n.m. \\
\hline $\mathrm{Ni}-59$ & $1.1 \mathrm{E}-03$ & 4.7E-04 & n.m. \\
\hline $\mathrm{Ni}-63$ & $1.1 \mathrm{E}-01$ & 4.7E-02 & n.m. \\
\hline Np-237 & $3.6 \mathrm{E}-05$ & $1.5 \mathrm{E}-05$ & 1.7E-05 \\
\hline Pu-238 & $3.8 \mathrm{E}-01$ & $1.6 \mathrm{E}-01$ & 1.4E-01 \\
\hline Pu-239 & $1.8 \mathrm{E}-02$ & 7.7E-03 & 7.7E-03 \\
\hline Pu-240 & $6.5 \mathrm{E}-03$ & $2.8 \mathrm{E}-03$ & 2.9E-03 \\
\hline Pu-241 & $<8.3 \mathrm{E}-02$ & $<3.5 \mathrm{E}-02$ & 3.7E-02 \\
\hline Pu-242 & $<1.5 \mathrm{E}-05$ & $<6.4 \mathrm{E}-06$ & $<1.4 \mathrm{E}-05$ \\
\hline Se-79 & $9.1 \mathrm{E}-06$ & $3.9 \mathrm{E}-06$ & n.m. \\
\hline Sm-151 & $2.6 \mathrm{E}-01$ & $1.1 \mathrm{E}-01$ & n.m. \\
\hline Sn-121m & $<4.7 \mathrm{E}-03$ & $<2.0 \mathrm{E}-03$ & n.m. \\
\hline Sn-126 & $<1.5 \mathrm{E}-04$ & $<6.4 \mathrm{E}-05$ & n.m. \\
\hline Sr-90 & $1.9 \mathrm{E}+01$ & $8.1 E+00$ & $5.9 \mathrm{E}+00$ \\
\hline Tc-99 & $<1.1 \mathrm{E}-04$ & $<4.8 \mathrm{E}-05$ & $<1.3 \mathrm{E}-04$ \\
\hline Th-232 & $2.4 \mathrm{E}-06$ & 1.0E-06 & 9.3E-07 \\
\hline U-233 & $9.0 \mathrm{E}-05$ & $3.8 \mathrm{E}-05$ & 7.0E-05 \\
\hline U-234 & $8.4 \mathrm{E}-05$ & $3.6 \mathrm{E}-05$ & 4.2E-05 \\
\hline U-235 & $6.0 \mathrm{E}-07$ & $2.6 \mathrm{E}-07$ & 2.3E-07 \\
\hline U-236 & $1.3 \mathrm{E}-06$ & 5.5E-07 & $6.3 \mathrm{E}-07$ \\
\hline U-238 & $1.2 \mathrm{E}-05$ & 5.1E-06 & $5.1 E-06$ \\
\hline Zr-93 & 4.60E-04 & $2.0 \mathrm{E}-04$ & 5.30E-04 \\
\hline Source & 32 & 43 & 32 \\
\hline
\end{tabular}

${ }^{*}$ Values in this Table are the measured values transcribed from those reported in the source(s) if not otherwise indicated. WAPS specification 1.2 requires the inventory of radionuclides that have half-lives longer than 10 years and contribute $>0.05 \%$ of the total Curie inventory indexed to the years 2015 and 3115 . (n.m. $=$ not measured)

${ }^{\mathrm{i}}$ The calculated values for radionuclides were obtained by dividing the sludge concentration by the SDF 2.35.

ii The measured Cs-137 is higher than calculated due to salt stream additions.

iii Measured Cs-137 concentration from the DWPF Production Inputs for SME batch 551 (see Table 4-2). 


\subsection{Variability Study}

Compositional uncertainties in the waste feed, projected waste loading ranges and the frit composition define a glass composition region over which a sludge batch may ultimately be processed at the DWPF. The variability study is intended to address the compositional uncertainties in the waste to be processed at the DWPF and attempts to ensure the uncertainties about a nominal waste feed composition once coupled with the recommended frit over waste loadings of interest will not put at risk the properties of the waste form. The variability study measures the PCT response for glasses in the possible compositional range that will be processed as a sludge batch and assesses the applicability of the durability models. In contrast, the sludge batch qualification sample glass evaluates a single composition which may, or may not, ultimately be processed. (see Section 4.2).

The intent of the variability study is to demonstrate applicability of the durability models to the composition range of the glass processing region. The variability study has evolved purposefully to evaluate a glass composition region dependent on the sludge batch processing plan in order to accommodate the various possible waste processing scenarios for each sludge batch. The variability study has been shown to be a robust method of predicting the product performance (durability) over a composition region given the current models used in developing a series of glasses for the variability study. Table 4-12 summarizes the reportable oxide components measured in the pour stream samples (wt. \%) and the minimum and maximum oxide quantities (wt. \%) evaluated in the corresponding variability study. ${ }^{\mathrm{n}}$ All of the oxide percentages measured in the pour stream samples were encompassed by their respective variability study ranges (percentages) indicating that the variability studies thus far have been designed correctly to evaluate the compositional regions of interest that included the pour stream samples.

Whereas the sludge batch qualification sample is a very narrow assessment of the applicability of the durability models to the compositional region (i.e. one data point) that could ultimately be processed in DWPF, the variability study provides an assessment of the applicability of the models over a broad composition region for the expected glass system to be processed based on waste composition predictions. (The Tank Farm provides predictions to SRNL based on its planned blending strategy for a given sludge batch). Because the variability study is dependent solely on compositional inputs, the variability study can be performed independent of the DWPF's macrobatch processing plan. In that way, the variability study has the flexibility to adjust for glass compositions as sludge composition predictions change, as new frits are defined, and as additional waste streams are added to the sludge stream. Moreover, because the variability study design does not depend on the processing methods operating upstream from the melter, any blending, mixing, and processing of the waste in the tank farm, in auxiliary units, or at the DWPF are inherently accounted for. The variability study therefore, is adequate to assess sludge-only operations, coupled operations, and foreseeable operations such as the incorporation of the salt streams from SWPF or the small column ion exchange (SCIX) processes.

\footnotetext{
${ }^{\mathrm{n}}$ The variability study evaluates many more constituent oxides than listed in Table 4-8. Only those components greater than $0.5 \mathrm{wt} . \%$ (in glass) are shown for simplicity.
} 
Table 4-12. Target Composition Ranges for the Variability Studies Compared to the Measured Pour Stream Samples for WAPS Reportable Chemical Compositions for SB1A through SB6."

\begin{tabular}{|c|c|c|c|c|c|c|c|c|c|c|c|c|c|c|c|c|c|c|c|c|c|}
\hline \multirow{3}{*}{ Oxide } & \multicolumn{3}{|c|}{ SB1A (wt. \%) } & \multicolumn{3}{|c|}{ SB1B (wt. \%) } & \multicolumn{3}{|c|}{ SB2 (wt. \%) } & \multicolumn{3}{|c|}{ SB3 (wt. \%) } & \multicolumn{3}{|c|}{ SB4 (wt. \%) } & \multicolumn{3}{|c|}{ SB5 (wt. \%) } & \multicolumn{3}{|c|}{ SB6 (wt. \%) } \\
\hline & \multicolumn{2}{|c|}{$\begin{array}{c}\text { Variability } \\
\text { Study }\end{array}$} & \multirow{2}{*}{$\begin{array}{c}\text { Pour } \\
\text { Stream }^{\dagger} \\
\text { Meas. }\end{array}$} & \multicolumn{2}{|c|}{$\begin{array}{l}\text { Variability } \\
\text { Study }\end{array}$} & \multirow{2}{*}{$\begin{array}{c}\begin{array}{c}\text { Pour } \\
\text { Stream }\end{array} \\
\text { Meas. }\end{array}$} & \multicolumn{2}{|c|}{$\begin{array}{l}\text { Variability } \\
\text { Study }\end{array}$} & \multirow{2}{*}{$\begin{array}{c}\text { Pour } \\
\text { Stream }\end{array}$} & \multicolumn{2}{|c|}{$\begin{array}{c}\text { Variability } \\
\text { Study }\end{array}$} & \multirow{2}{*}{$\begin{array}{c}\text { Pour } \\
\text { Stream }\end{array}$} & \multicolumn{2}{|c|}{$\begin{array}{c}\text { Variability } \\
\text { Study }\end{array}$} & \multirow{2}{*}{$\begin{array}{c}\text { Pour } \\
\text { Stream }\end{array}$} & \multicolumn{2}{|c|}{$\begin{array}{c}\text { Variability } \\
\text { Study }\end{array}$} & \multirow{2}{*}{$\begin{array}{l}\text { Pour } \\
\text { Strea }\end{array}$} & \multicolumn{2}{|c|}{$\begin{array}{l}\text { Variability } \\
\text { Study }\end{array}$} & \multirow{2}{*}{$\begin{array}{c}\begin{array}{c}\text { Pour } \\
\text { Stream }\end{array} \\
\text { Meas. }\end{array}$} \\
\hline & Min & Max & & Min & Max & & Min & Max & & Min & Max & & Min & Max & & Min & Max & & Min & Max & \\
\hline $\mathrm{Al}_{2} \mathrm{O}_{3}$ & 3.1 & 5.4 & 4.3 & 2.5 & 7.9 & 5.4 & 3.1 & 7.4 & 4.3 & 4.4 & 8.3 & 4.8 & 7.4 & 11.4 & 7.8 & 5.1 & 8.1 & 6.7 & 8.3 & 10.9 & 8.6 \\
\hline $\mathrm{B}_{2} \mathrm{O}_{3}$ & 4.9 & 9.7 & 8.2 & 7.9 & 9.8 & 8.2 & 4.1 & 9.0 & 4.4 & 4.1 & 13.9 & 4.4 & 4.5 & 9.8 & 8.9 & 4.8 & 6.0 & 5.6 & 4.4 & 5.3 & 4.6 \\
\hline $\mathrm{CaO}$ & 0.8 & 1.8 & 1.3 & 0.4 & 2.4 & 1.4 & 0.9 & 1.9 & 1.3 & 0.8 & 1.7 & 1.0 & 0.7 & 1.2 & 0.7 & 0.5 & 1.0 & 0.7 & 0.3 & 0.9 & 0.6 \\
\hline $\mathrm{Fe}_{2} \mathrm{O}_{3}$ & 7.8 & 18.7 & 12.6 & 5.2 & 15.0 & 10.5 & 8.8 & 16.0 & 12.2 & 8.3 & 16.4 & 10.8 & 7.0 & 11.5 & 8.2 & 6.7 & 10.6 & 8.5 & 6.2 & 9.2 & 8.7 \\
\hline $\mathrm{Li}_{2} \mathrm{O}$ & 3.4 & 5.8 & 3.6 & 3.1 & 4.2 & 3.5 & 3.3 & 6.2 & 5.3 & 2.0 & 6.1 & 5.0 & 4.3 & 5.7 & 5.3 & 4.7 & 5.7 & 5.6 & 4.5 & 5.3 & 4.9 \\
\hline MgO & 1.7 & 2.2 & 2.1 & 1.2 & 2.9 & 2.2 & 0.0 & 2.8 & 1.2 & 0.0 & 1.4 & 1.2 & 0.7 & 1.2 & 0.8 & 0.3 & 0.8 & 0.5 & 0.1 & 0.6 & 0.3 \\
\hline $\mathrm{MnO}$ & 0.8 & 1.7 & 1.1 & 0.6 & 1.9 & 1.8 & 0.6 & 2.9 & 1.5 & 1.5 & 2.8 & 2.1 & 1.5 & 2.5 & 1.6 & 1.5 & 2.2 & 1.7 & 2.1 & 3.2 & 2.2 \\
\hline $\mathrm{Na}_{2} \mathrm{O}$ & 7.4 & 12.4 & 12.1 & 8.8 & 13.9 & 11.5 & 9.3 & 15.0 & 11.3 & 8.9 & 18.8 & 11.9 & 9.7 & 14.7 & 11.5 & 11.3 & 15.4 & 13.4 & 12.9 & 19.4 & 14.9 \\
\hline $\mathrm{NiO}$ & & & & 0.1 & 0.6 & 0.2 & 0.4 & 0.8 & 0.6 & 0.3 & 0.6 & 0.6 & 0.3 & 0.8 & 0.5 & 0.7 & 1.2 & 1.0 & 0.8 & 1.5 & 1.0 \\
\hline $\mathrm{SiO}_{2}$ & 41.1 & 67.0 & 48.1 & 47.0 & 55.8 & 52.4 & 43.0 & 54.8 & 49.3 & 41.4 & 56.6 & 51.0 & 41.8 & 55.2 & 50.7 & 47.4 & 57.2 & 54.6 & 45.0 & 54.1 & 49.1 \\
\hline $\mathrm{ThO}_{2}$ & & & & & & & & & & & & & & & & & & & 0.9 & 1.1 & 1.0 \\
\hline $\mathrm{U}_{3} \mathrm{O}_{8}$ & 0.5 & 1.1 & 1.0 & 0.0 & 1.3 & 1.1 & 1.9 & 4.6 & 3.4 & 2.1 & 4.0 & 3.5 & 2.2 & 3.6 & 2.2 & 1.8 & 3.0 & 2.2 & 1.4 & 2.4 & 1.8 \\
\hline Source & & 9,56 & & & $13,14,5$ & & & $37,58,5$ & & & $20,59,6$ & & & $25,61-$ & & & 25,65 & & & 32,66 & \\
\hline
\end{tabular}




\subsection{Conclusions and Recommendations}

This report specifically assessed the impact of the proposed elimination of the characterization of pour stream glass samples and the elimination of the glass fabrication and PCT of the sludge batch qualification sample on sludge batches processed using coupled operations. SB4, SB5 and SB6 were processed with auxiliary MCU and ARP streams, and the pour stream data for SB5 and SB6 were determined to be representative of SME batches with the auxiliary waste streams added. An evaluation of the sludge-only operation and coupled operation data has not identified any insufficiency in the SRNL qualification activities or DWPF process control or reporting activities of the GPCP.

The data generated by the characterization of pour stream samples taken from the sludge batches processed to date in the DWPF have provided confirmation that the DWPF has consistently met WAPS Specifications 1.1, 1.2, 1.3, and 1.6. ${ }^{6}$ The GPCP has been successful in directing activities that produce a waste form that is compliant with the WAPS, and under the direction of that program the DWPF should continue to produce a compliant waste form that does not rely on the characterization of pour stream samples or the glass fabrication and PCT of the sludge batch qualification sample.

The impact of the SWPF startup is not anticipated to change the fundamental conclusions presented in this report. The SWPF is essentially a higher volume capacity MCU and ARP and as such, the effect of the SWPF on the coupled operation is to increase the amount of salt fed into the DWPF by providing for a more continuous auxiliary salt stream feed. A new solvent system which uses boric acid is being considered for use in the MCU and the SWPF. A preliminary evaluation indicated that the addition of boric acid to the waste stream would be expected to have minimal effect on the overall waste composition (provided the concentration is less than $\sim 0.01$ molar) since the $\mathrm{B}_{2} \mathrm{O}_{3}$ contribution to the glass could be controlled with frit adjustments. ${ }^{67,68}$ Furthermore, the variability study will address the impact of these auxiliary streams (SWFP, SCIX, boric acid, etc) on waste form performance and model applicability.

The DWPF has been producing an acceptable product for sixteen years under the direction of the GPCP and the WCP. The DWPF's compliance strategy for the waste form to meet the WAPS specifications is derived from process control information ${ }^{69}$, but, historically, has been supported by the characterization of pour stream glass samples and the glass fabrication and PCT measurement of the sludge batch qualification samples. The elimination of the characterization of pour stream glass samples and the elimination of the glass fabrication and PCT of the sludge batch qualification sample does not compromise the DWPF's compliance strategy provided the variability study remains a key component of the GPCP.

The DWPF's fundamental philosophy for waste form compliance has not changed; however, the DWPF has made several changes to its compliance strategy from a practicality standpoint since production began sixteen years ago. Some of those changes are reflected in the WCP whereas others are not. The DWPF should update the WCP to reflect changes that have been implemented over the previous years as well as any changes that would be associated with the elimination of pour stream sample characterization and the sludge batch qualification sample characterization. 


\subsection{References}

1. A. D. Daniel and L. Sonnenberg, "Eliminate Non-Value Added Activities for Sludge Batch Qualification Program," Six Sigma-Lean Report SS-PIP-2006-00030, Westinghouse Savannah River Company, Aiken, SC (2007).

2. C. C. Herman, D. K. Peeler and T. B. Edwards, "Technical Justification for Elimination of Glass Fabrication and Testing for DWPF Qualification Sample," Inter-Office Memorandum SRNL-PSE-2007-00080, Savannah River National Laboratory, Aiken, SC (2007).

3. C. C. Herman, N. E. Bibler and T. B. Edwards, "Technical Justification for Elimination of Characterization of DWPF Pour Stream Samples," Inter-Office Memorandum SRNLPSE-2007-00079, Savannah River National Laboratory, Aiken, SC (2007).

4. J. W. Ray, "Evaluation of DWPF Pour Stream Glass Sample Analysis and Glass Fabrication/Testing of DWPF Qual Samples," Technical Task Request (TTR) HLWDWPF-TTR-2012-0006, Aiken, SC (2011).

5. J. W. Amoroso, D. K. Peeler and T. B. Edwards, "Task Technical and Quality Assurance Plan for Evaluation of DWPF Pour Stream Glass Sample Analysis and Glass Fabrication/Testing of DWPF Qualification Samples," US Department of Energy Report SRNL-RP-2011-01692, Savannah River National Laboratory, Aiken, SC (2012).

6. "Waste Acceptance Product Specifications (WAPS) for Vitrified High-Level Waste Forms," US Department of Energy Report DOE/EM-0093 Revision 2, Office of Environmental Management, (1996).

7. "DWPF Glass Product Control Program," WSRC-IM-91-116-6, Revision 6, Washington Savannah River Company, Aiken, SC (2006).

8. A. V. Staub, "Reporting the Radionuclide Inventory of the DWPF Product," $X$-CLC-S00107, Aiken, SC (2002).

9. T. L. Fellinger and N. E. Bibler, "DWPF Glass Results for the Analysis of a Pour Stream Sample Taken During Pouring the $409^{\text {th }}$ Canister (Canister S00834) in Macrobatch 1," US Department of Energy Report WSRC-RP-98-01400, Westinghouse Savannah River Company, Aiken, SC (1998).

10. D. M. Ferrara, N. E. Bibler, M. S. Hay, B. C. Ha and M. K. Andrews, "Shielded Cells Batch 1 - Sludge Only Campaign with Tank 51 Sludge and Frit 200," US Department of Energy Report WSRC-TR-95-0481, Westinghouse Savannah River Company, Aiken, SC (1995).

11. T. L. Fellinger, N. E. Bibler and J. R. Harbour, "Characterization of and Waste Acceptance Radionuclides to be Reported for DWPF Macro Batch 2 (ESP 215-ESP 221)," US Department of Energy Report WSRC-RP-99-00436, Rev. 1, Westinghouse Savannah River Company, Aiken, SC (2004). 
12. A. V. Staub, "Reporting the Radionuclide Inventory of Macrobatch 2," X-CLC-S-00135, Aiken, SC (2004).

13. N. E. Bibler and T. L. Fellinger, "Analytical Results of DWPF Glass Sample Taken During Pouring of Canister S01142: Summary Report, Rev. 1," US Department of Energy Report WSRC-RP-2000-00686, Rev. 1, Westinghouse Savannah River Company, Aiken, SC (2004).

14. T. L. Fellinger and N. E. Bibler, "Results of the Chemical Composition and the Product Consistency Test for the DWPF Macro Batch 2 Glass Pour Stream Sample Taken During the Pouring of Canister S01142," US Department of Energy Report WSRC-RP-200000281, Westinghouse Savannah River Company, Aiken, SC (2000).

15. A. V. Staub, "Reporting the Radionuclide Inventory of Macrobatch 3," X-CLC-S-00143, Aiken, SC (2006).

16. A. D. Cozzi, N. E. Bibler and C. J. Bannochie, "Analytical Results of DWPF Glass Sample Taken During Filling of Canister S01913," US Department of Energy Report WSRC-TR-2004-00316, Rev. 2, Westinghouse Savannah River Company, Aiken, SC (2005).

17. N. E. Bibler, D. P. DiPrete and J. R. Harbour, "Determination of Reportable Radionuclides for DWPF Sludge Batch 2 (Macro Batch 3)," US Department of Energy Report WSRC-TR-2002-00255, Westinghouse Savannah River Company, Aiken, SC (2002).

18. T. L. Fellinger, J. M. Pareizs, N. E. Bibler, A. D. Cozzi and C. L. Crawford, "Confirmation Run of the DWPF SRAT Cycle Using the Sludge-Only Flowsheet with Tank 40 Radioactive Sludge and Frit 200 in the Shielded Cells Facility," US Department of Energy Report WSRC-TR-2002-00076, Westinghouse Savannah River Company, Aiken, SC (2002).

19. T. L. Fellinger, J. M. Pareizs, N. E. Bibler, A. D. Cozzi and C. L. Crawford, "Confirmation Run of the DWPF SME Cycle and Results of the Glass Analysis Using the Sludge-Only Flowsheet with Tank 40 Radioactive Sludge and Frit 200 in the Shielded Cells Facility," US Department of Energy Report WSRC-TR-2002-00096, Westinghouse Savannah River Company, Aiken, SC (2002).

20. C. J. Bannochie and N. E. Bibler, "Analysis of Sludge Batch 3 (Macrobatch 4) DWPF our Stream Glass Sample for Canister S02312," US Department of Energy Report WSRCTR-2005-00354, Westinghouse Savannah River Company, Aiken, SC (2005).

21. P. L. Bovan, "Reporting the Radionuclide Inventory of Macrobatch 4," X-CLC-S-00172, Aiken, SC (2009).

22. C. J. Bannochie, T. L. Fellinger and J. M. Pareizs, "Tank 40 Final SB3 Chemical Characterization Results," US Department of Energy Report WSRC-TR-2005-00049, Westinghouse Savannah River Company, Aiken, SC (2005).

23. C. J. Bannochie, N. E. Bibler and D. P. DiPrete, "Determination of Reportable Radionuclides for DWPF Sludge Batch 4 (Macrobatch 5)," US Department of Energy 
Report WSRC-STI-2008-00142, Westinghouse Savannah River Company, Aiken, SC (2008).

24. H. H. Elder, "Reporting the Radionuclide Inventory of Macrobatch 5," X-CLC-S-00180, Aiken, SC (2011).

25. M. M. Reigel and N. E. Bibler, "Analysis of Sludge Batch 4 (Macrobatch 5) for Canister S02902 and Sludge Batch 5 (Macrobatch 6) for Canister S03317 DWPF Pour Stream Glass Samples," US Department of Energy Report SRNL-STI-2010-00435, Savannah River National Laboratory, Aiken, SC (2010).

26. C. J. Bannochie, "Tank 40 Final SB4 Chemical Characterization Results," US Department of Energy Report WSRC-STI-2007-00674, Westinghouse Savannah River Company, Aiken, SC (2008).

27. C. J. Bannochie, N. E. Bibler and D. P. DiPrete, "Determination of Reportable Radionuclides for DWPF Sludge Batch 5 (Macrobatch 6)," US Department of Energy Report SRNL-STI-2009-00821, Savannah River National Laboratory, Aiken, SC (2010).

28. H. H. Elder, "Reporting the Radionuclide Inventory of Macrobatch 6," X-CLC-S-00183, Aiken, SC (2011).

29. C. J. Bannochie and D. R. Click, "Tank 40 Final SB5 Chemical Characterization Results Prior to Np Addition," US Department of Energy Report SRNL-STI-2009-00060, Rev. 2, Savannah River National Laboratory, Aiken, SC (2010).

30. C. J. Bannochie, "Tank 40 Final SB6 Chemical Characterization Results," US Department of Energy Report SRNL-STI-2010-00441, Savannah River National Laboratory, Aiken, SC (2010).

31. C. J. Bannochie and D. P. DiPrete, "Determination of Reportable Radionuclides for DWPF Sludge Batch 6 (Macrobatch 7)," US Department of Energy Report SRNL-STI2011-00189, Savannah River National Laboratory, Aiken, SC (2011).

32. F. C. Johnson, "Analysis of DWPF Sludge Batch 6 (Macrobatch 7) Pour Stream Glass Samples," US Department of Energy Report SRNL-STI-2011-00555, Savannah River National Laboratory, Aiken, SC (2012).

33. K. G. Brown, R. L. Postles and T. B. Edwards, "SME Acceptability Determination for DWPF Process Control," US Department of Energy Report WSRC-TR-95-0364, Rev. 5, Westinghouse Savannah River Company, Aiken, SC (2006).

34. A. V. Staub and J. W. Ray, "Data Input for Macrobatch 1 Production Records," Interoffice Memorandum HLW-DEN-2002-00051, Westinghouse Savannah River Company, Aiken, SC (2002).

35. A. V. Staub, "Reporting the Chemical Composition and Glass Durability of Macrobatch 2," X-CLC-S-00134, Aiken, SC (2004). 
36. J. W. Ray, "Data Input for Macrobatch 3 Production Records (Rev. 1)," Interoffice Memorandum LWO-WSE-2007-00037, Rev. 1, Washington Savannah River Company, Aiken, SC (2007).

37. A. D. Cozzi and N. E. Bibler, "Analytical Results of DWPF Glass Sample Taken During Filling of Canister S01913," US Department of Energy Report WSRC-TR-2004-00316, Rev. 1, Westinghouse Savannah River Company, Aiken, SC (2004).

38. J. W. Ray and P. L. Bovan, "Data Input for Macrobatch 4 Production Records," Interoffice Memorandum LWO-WSE-2009-00098, Washington Savannah River Company, Aiken, SC (2009).

39. C. J. Bannochie and N. E. Bibler, "Summary Report on the Analysis of Sludge Batch 3 (Macrobatch 4) DWPF our Stream Glass Sample for Canister S02312," US Department of Energy Report WSRC-TR-2005-00355, Westinghouse Savannah River Company, Aiken, SC (2005).

40. J. W. Ray, "Data Input and Verification for Macrobatch 5 Production Records," Interoffice Memorandum SRR-WSE-2011-00150, Savannah River Remediation, LLC, Aiken, SC (2011).

41. H. H. Elder, "Reporting the Chemical Composition and Glass Durability of Macrobatch 5," X-CLC-S-00179, Aiken, SC (2004).

42. H. H. Elder, "Reporting the Chemical Composition and Glass Durability of Macrobatch 6," X-CLC-S-00182, Aiken, SC (2011).

43. Personal Communication with H. H. Elder. Production Records inputs for SB6 were not issued as this report was being prepared. Chemical composition, radionuclide inventories, and PCT responses were available in the QA Process Batch Records. The data provided by $H$. $H$. Elder was compiled from the QA Process Batch Sheets. Aiken, SC, February - March 2012.

44. F. C. Johnson, "Summary Report for the Analysis of the Sludge Batch 6 (Macrobatch 7) DWPF Pour Stream Glass Sample for Canister S03472," US Department of Energy Report SRNL-STI-2012-00039, Savannah River National Laboratory, Aiken, SC (2012).

45. C. M. Jantzen, J. B. Pickett, K. G. Brown, T. B. Edwards and D. C. Beam, "Process/Product Models for the Defense Waste Processing Facility (DWPF): Part I. Predicting Glass Durability from Composition Using Thermodynamic Hydration Energy Reaction Model (THERMO)," US Department of Energy Report WSRC-TR-93-672, Revision 1, Westinghouse Savannah River Company, Aiken, SC (1995).

46. SAS Institute, Inc., JMP, 7.0, Cary, North Carolina.

47. A. V. Staub, "Reporting the Chemical Composition and Glass Durability of Macrobatch 1," X-CLC-S-00102, Aiken, SC (2001).

48. O. B. Hodoh and N. E. Bibler, "DWPF Glass Results for the Analysis of Sample PC1T from Canister S00424.," US Department of Energy Report WSRC-RP-96-00414, Westinghouse Savannah River Company, Aiken, SC (1996). 
49. O. B. Hodoh and N. E. Bibler, "DWPF Glass Results for the Analysis of Sample PC0001 from Canister S00431.," US Department of Energy Report WSRC-RP-96-00529, Westinghouse Savannah River Company, Aiken, SC (1996).

50. T. L. Fellinger, N. E. Bibler and O. B. Hodoh, "DWPF Glass Results for the Analysis of a Pour Stream Sample Taken During Pouring of the $50^{\text {th }}$ Canister (Canister S00471)." US Department of Energy Report WSRC-RP-98-00053, Westinghouse Savannah River Company, Aiken, SC (1998).

51. T. L. Fellinger, N. E. Bibler and O. B. Hodoh, "DWPF Glass Results for the Analysis of a Pour Stream Sample Taken During Pouring of the $61^{\text {st }}$ Canister (Canister S00482)." US Department of Energy Report WSRC-RP-98-00054, Westinghouse Savannah River Company, Aiken, SC (1998).

52. H. H. Elder, "Reporting the Chemical Composition and Glass Durability of Macrobatch 5," X-CLC-S-00179, Aiken, SC (2011).

53. C. M. Jantzen, N. E. Bibler, D. C. Beam, C. L. Crawford and M. A. Pickett, "Characterization of the Defense Waste Processing Facility (DWPF) Environmental Assessment (EA) Glass Standard Reference Material," US Department of Energy Report WSRC-TR-92-346, Westinghouse Savannah River Company, Aiken, SC (1993).

54. A. V. Staub, J. W. Ray, T. B. Edwards, N. E. Bibler and S. L. Marra, "Reporting the Radionuclide Inventory of the DWPF Product," WSRC-IM-91-116-4, Rev. 2, Washington Savannah River Company, Aiken, SC (2003).

55. N. E. Bibler and T. L. Fellinger, "Results of the Radionuclide Composition for the DWPF Macro Batch 2 Glass Pour Stream Sample Taken During the Pouring of Canister S01142, Rev. 1," US Department of Energy Report WSRC-RP-2000-00418, Westinghouse Savannah River Company, Aiken, SC (2004).

56. D. K. Peeler, "Batch 1 Variability Study Using Twice Washed tank 51 Sludge," US Department of Energy Report WSRC-RP-95-01045, Rev. 1, Westinghouse Savannah River Company, Aiken, SC (1996).

57. C. C. Herman, M. K. Andrews and T. B. Edwards, "Results of the Tank 42 (Batch 1B) Variability Study," US Department of Energy Report WSRC-TR-98-00180, Westinghouse Savannah River Company, Aiken, SC (1998).

58. C. C. Herman, T. B. Edwards and D. M. Marsh, "Summary of Results for Expanded Macrobatch 3 Variability Study," US Department of Energy Report WSRC-TR-200100511, Westinghouse Savannah River Company, Aiken, SC (2001).

59. T. H. Lorier, T. B. Edwards, I. A. Reamer, D. R. Best and D. K. Peeler, "SB3 Phase 2 Variability Study: The Impact of Redox on Durability for the Frit 418-SB2/3," US Department of Energy Report WSRC-TR-2003-00539, Westinghouse Savannah River Company, Aiken, SC (2003).

60. D. K. Peeler, T. B. Edwards, C. C. Herman, T. H. Lorier, D. R. Best, I. A. Reamer and R. J. Workman, "Sludge Batch 3 Phase 1 Variability Study," US Department of Energy 
Report WSRC-TR-2002-00549, Westinghouse Savannah River Company, Aiken, SC (2003).

61. K. M. Fox, T. B. Edwards, D. K. Peeler, D. R. Best, I. A. Reamer and R. J. Workman, "High Level Waste (HLW) Sludge Batch 4 (SB4) Variability Study," US Department of Energy Report WSRC-STI-2006-00204, Westinghouse Savannah River Company, Aiken, SC (2006).

62. F. C. Raszewski, T. B. Edwards, D. K. Peeler, D. R. Best, I. A. Reamer and R. J. Workman, "Initial Sludge Batch 4 Tank 40 Decant Variability Study with Frit 510," US Department of Energy Report WSRC-STI-2008-00149, Westinghouse Savannah River Company, Aiken, SC (2008).

63. F. C. Raszewski, T. B. Edwards, D. K. Peeler, D. R. Best, I. A. Reamer and R. J. Workman, "Variability Study with Frit 510 to Support a Second Tank 40 Decant," US Department of Energy Report WSRC-STI-2008-00315, Westinghouse Savannah River Company, Aiken, SC (2008).

64. K. M. Fox, T. B. Edwards, D. K. Peeler, D. R. Best, I. A. Reamer and R. J. Workman, "High Level Waste (HLW) Sludge Batch 4 (SB4) with Frit 418: Results of a Phase II Variability Study," US Department of Energy Report WSRC-STI-2006-00329, Westinghouse Savannah River Company, Aiken, SC (2006).

65. F. C. Raszewski, T. B. Edwards and D. K. Peeler, "Sludge Batch 5 Variability Study with Frit 418," US Department of Energy Report SRNS-STI-2008-00065, Savannah River National Laboratory, Aiken, SC (2008).

66. F. C. Johnson and T. B. Edwards, "Sludge Batch 6 Variability Study with Frit 418," US Department of Energy Report SRNL-STI-2010-00242, Savannah River National Laboratory, Aiken, SC (2010).

67. M. E. Stone, "Preliminary Evaluation of DWPF Impacts of Boric Acid Use in Cesium Strip for SWPF and MCU," US Department of Energy Report SRNL-STI-2010-00594, Savannah River National Laboratory, Aiken, SC (2010).

68. D. K. Peeler and T. B. Edwards, "The Impact of the MCU Life Extension Solvent on DWPF Glass Formulation Efforts," US Department of Energy Report SRNL-STI-201100110, Savannah River National Laboratory, (2011).

69. "DWPF Waste Form Compliance Plan," WSRC-IM-91-116-0, Revision 8, Washington Savannah River Company, Aiken, SC (2006). 


\section{Distribution:}

J. W. Amoroso, 999-W

B. N. Attaway, 773-A

C. J. Bannochie, 773-42A

J. M. Bricker, 704-27S

M. A. Broome, 704-29S

C. L. Crawford, 773-42A

T. B. Edwards, 999-W

H. H. Elder, 704-24S

T. L. Fellinger, 704-26S

S. D. Fink, 773-A

K. M. Fox, 999-W

B. J. Giddings, 786-5A

J. M. Gillam, 766-H

B. A. Hamm, 766-H

C. C. Herman, 999-W

R. N. Hinds, 704-S

E. W. Holtzscheiter, 704-15S

J. F. Iaukea, 704-30S

P. R. Jackson, DOE-SR,

V. Jain, 704-30S

C. M. Jantzen, 773-A

F. C. Johnson, 999-W

M. T. Keefer, 766-H

D. C. Koopman, 999-W

D. P. Lambert, 999-W

S. L. Marra, 773-A

D. W. McIlmoyle, 766-H

D. J. Newell, 999-W

J. E. Occhipinti, 704-S

J. M. Pareizs, 773-A

D. K. Peeler, 999-W

F. M. Pennebaker, 773-42A

J. W. Ray, 704-S

S. H. Reboul, 773-A

M. A. Rios-Armstrong, 241-156H

A. R. Shafer, 241-197H

H. B. Shah, 766-H

D. C. Sherburne, 704-S

A. V. Staub, 704-27S

M. E. Stone, 999-W

K. H. Subramanian, 766-H

J. P. Vaughan, 773-41A

W. R. Wilmarth, 773-A 